\author{
Universidade de São Paulo \\ Instituto de Física \\ Instituto de Química \\ Instituto de Biociências \\ Faculdade de Educação
}

Estefânia Bettio Sanches de Araujo

\title{
Química e sociedade em livros universitários de química geral
}

São Paulo

2015 


\section{ESTEFÂNIA BETTIO SANCHES DE ARAUJO}

\section{Química e sociedade em livros universitários de química geral}

Dissertação apresentada ao Instituto de Física, Instituto de Química, Instituto de Biociências e a Faculdade de Educação da Universidade de São Paulo, para a obtenção do título de Mestre em Ensino de Ciências, modalidade Química.

Orientador: Paulo Alves Porto

São Paulo

2015

Versão Corrigida 
Autorizo a reprodução e divulgação total ou parcial deste trabalho, por qualquer meio convencional ou eletrônico, para fins de estudo e pesquisa, desde que citada a fonte.

\section{FICHA CATALOGRÁFICA \\ Preparada pelo Serviço de Biblioteca e Informação do Instituto de Física da Universidade de São Paulo}

Araujo, Estefânia Bettio Sanches de

Química e sociedade em livros universitários de química geral.

São Paulo, 2015.

Dissertação (Mestrado) - Universidade de São Paulo. Faculdade de Educação, Instituto de Física, Instituto de Química e Instituto de Biociências.

Orientador: Prof. Dr. Paulo Alves Porto

Área de Concentração: Química

Unitermos: 1.Química - Estudo e ensino; 2. Química e sociedade;

3. Imagem da química; 4. Livros didáticos.

USP/IF/SBI-124/2015 


\section{Agradecimentos}

Agradeço primeiramente ao meu orientador, Prof. Dr. Paulo Alves Porto, por sua dedicação, paciência e por me mostrar uma área que eu não tinha estudado antes em profundidade, que é a filosofia da química. Obrigada por tudo! Aproveito para agradecer à Prof $\stackrel{a}{\text {. Dra }}$. Paola Corio pelo carinho!

Obrigada à Profㄹ. Drª. Daisy de Brito Rezende, por me ensinar a pensar logicamente, não me fechar dentro da minha própria cabeça, a questionar meus pensamentos e a enfrentar os meus problemas.

Agradeço ao Prof. Dr. Flavio Antonio Maximiano, pelas dicas, pela ajuda neste trabalho e pela disposição.

Obrigada à minha família, por tudo que fizeram por mim, não tenho palavras para agradecer a cada um de vocês (obrigada, Paula!).

Obrigada ao meu marido, Danilo Martins de Araujo, pelo carinho, amor, apoio e principalmente, incentivo e por me mostrar que tenho um longo caminho pela frente.

Obrigada aos meus amigos: Prof ${ }^{\mathrm{a}}$. Fabiana Rodrigues, Tassiana Rozon, Carolina Rebelo, Ana Rocha, David Barbosa por não desistirem de mim, mesmo quando estava completamente ausente.

Obrigada aos meus colegas do grupo GHQ, por todo o conhecimento compartilhado, por todos os momentos divertidos; agradeço em especial ao Winston, Zé Otávio, Anielli, Marcos e Evandro, que me acompanharam mais de perto.

Obrigada ao Dr. Marco Boni por literalmente salvar a minha vida (mil vezes obrigada!) e à $\mathrm{Dr}^{\mathrm{a}}$. Ana Luiza Ferrão, por clarear minha mente e me mostrar que tenho solução! 
Agradeço a Deus e Nossa Senhora de Fátima, Santo Expedito, Santa Terezinha, São João Paulo II e toda aquela turma que está sempre me guardando.

Foi um período de grande amadurecimento pessoal, acredito que tudo isso gerou uma mudança positiva que vai determinar como serei daqui em diante. Ainda tenho muito a refletir, foram muitas lições apreendidas. Sou muito grata por ter tido essa oportunidade. 


\section{Resumo}

Araujo, E. B. S. Química e sociedade em livros universitários de química geral. 2015. 73f. Dissertação de Mestrado - Instituto de Física, Instituto de Química, Instituto de Biociências e Faculdade de Educação - Programa Interunidades em Ensino de Ciências, Universidade de São Paulo, São Paulo, 2015.

A atual pesquisa científica possui características próprias resultantes de um processo histórico longo, demorado e denso. Para se compreender a importância da química dentro da sociedade é preciso levar em consideração os caminhos percorridos historicamente por essa ciência. Considerando que a ciência existe na mente dos cientistas, e que não existe uma maneira pré-determinada para a prática da ciência, torna-se de extrema importância a qualidade na formação do cientista. $O$ químico formado, que tanto pode atuar na indústria quanto na área acadêmica, precisa seguir uma série de condutas éticas e ser um profissional reflexivo. O livro didático se constitui em veículo privilegiado para a comunidade química projetar as visões que considera adequadas para serem assimiladas pelo futuro profissional a respeito da química, as quais podem se diferenciar de acordo com as intenções do autor. Esta dissertação buscou selecionar e analisar alguns livros didáticos de química geral utilizados no ensino universitário de química, a fim de investigar as relações entre química e sociedade apresentadas neles. Os resultados mostram que os livros didáticos analisados atendem, de maneira ampla, ao estudante que se formará um químico para a indústria, mais do que a um químico acadêmico. Em todos os livros didáticos analisados foram encontradas menções a algum problema ambiental, em geral abordados como se fossem um percalço no trabalho dos químicos, algo como um acidente inevitável. Além da ausência de autocrítica a respeito da atuação dos químicos, foi encontrada a valorização do cientista como um transformador social. A abordagem histórica nos livros é feita de maneira superficial, limitando-se a nomes e datas. Os resultados sugerem que os autores de livros didáticos não se propõem a incluir neles conteúdos e atividades que poderiam proporcionar uma formação mais completa e diversificada, no sentido de problematizar o papel da química na sociedade. Uma formação mais crítica poderia colocar melhores profissionais no mercado, mais cientes de seus compromissos éticos, para além do domínio técnico de suas áreas de atuação.

Palavras-chave: Ensino de Química, química e sociedade, imagem da química, livros didáticos. 


\begin{abstract}
Araujo, E. B. S. Chemistry and society in university level general chemistry textbooks. 2015. 73f. Dissertation (Master in Science Education - Chemical Education) - Instituto de Física, Instituto de Química, Instituto de Biociências and Faculdade de Educação - Programa Interunidades em Ensino de Ciências, Universidade de São Paulo, São Paulo, 2015.

Current scientific research has its own characteristics resulting from a long and dense historical process. To understand the relevance of chemistry in society it is necessary to take into account the historical paths taken by this science. Whereas science exists in the minds of scientists, and that there is no predetermined way to the practice of science, quality becomes extremely important in the formation of scientists. Professional chemists acting either in industry or academia need to follow a series of ethical guidelines and be reflective in their tasks. Textbooks constitute excellent vehicles for the diffusion of issues the chemical community consider appropriate to be assimilated by future professionals concerning chemistry. Such issues may differ according to the author's intentions. This research aimed at selecting and analyzing general chemistry textbooks used in university level chemistry courses in order to investigate the relationships between chemistry and society presented in them. Results show that the analyzed textbooks are mainly aimed at students who will work as chemists in industries, more than in universities. In all analyzed textbooks were found mentions on at least one environmental problem, and in general such problems were addressed as a mishap in chemists' work, or something like an unavoidable accident. Besides the absence of selfcriticism about the professional performance of chemists, scientists are presented as the agents of benign social changes. The historical approach in the textbooks is superficially done, usually consisting of a mere mention of names and dates. The results suggest that textbook authors do not consider the inclusion of contents and activities that could provide a more complete and diverse education by discussing the role of chemistry in society. A more critical training could put better professionals in the market: chemists more aware of their ethical commitments, beyond the technical mastery of their area of expertise.
\end{abstract}

Keywords: Chemical Education, chemistry and society, image of chemistry, textbooks. 


\section{Sumário}

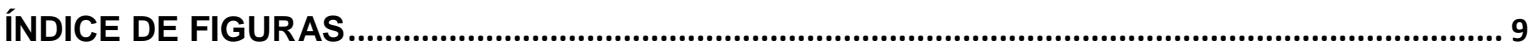

INTRODUÇÃO

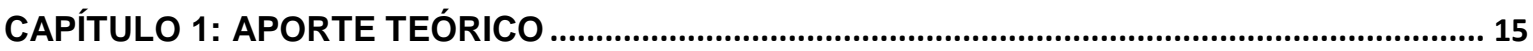

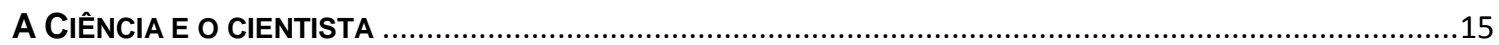

A IMAGEM DA QUÍMICA NA SOCIEDADE

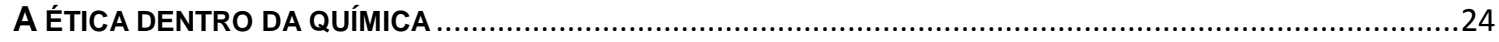

O LIVRO DIDÁTICO

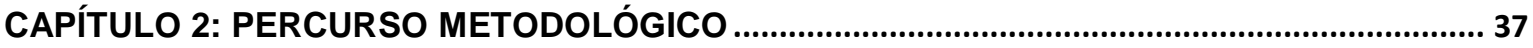

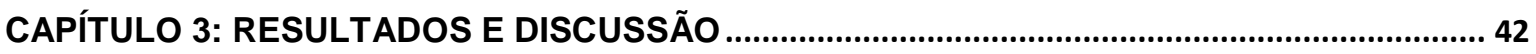

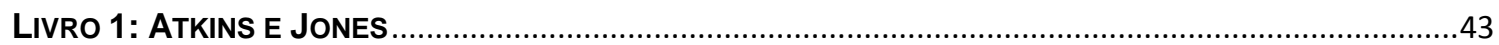

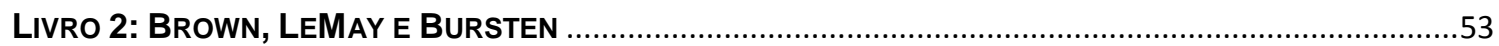

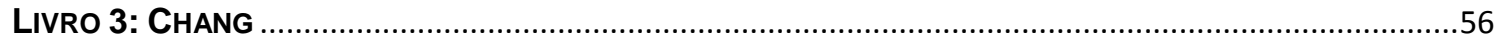

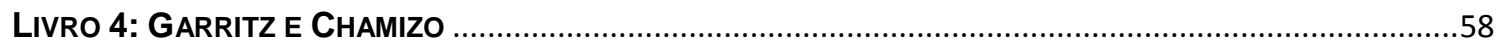

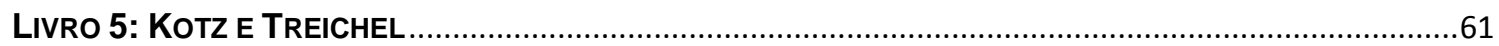

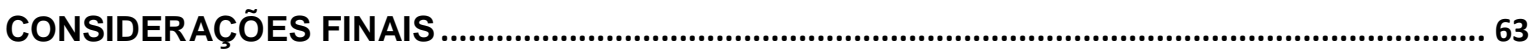

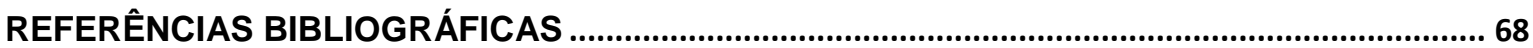




\section{Índice de Figuras}

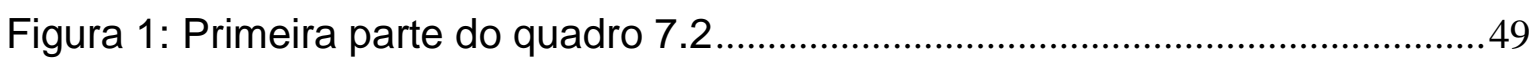

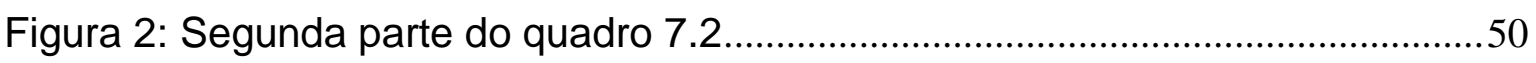

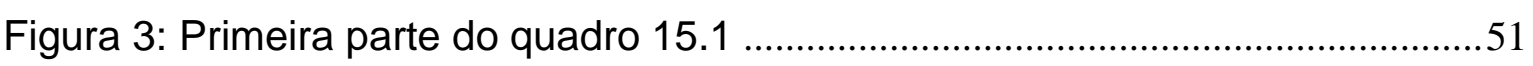

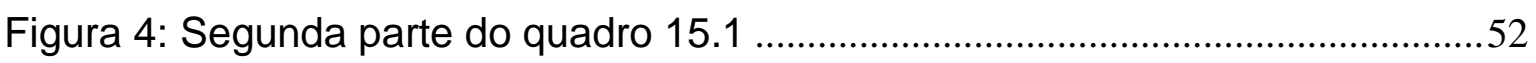




\section{Introdução}

Com o passar do tempo, a química se arraigou no nosso cotidiano ao ponto de não mais nos darmos conta de sua importância. A química foi, provavelmente, a ciência moderna cujos resultados provocaram as mudanças mais profundas sobre o modo de vida das sociedades. O crescimento da indústria química a partir das últimas décadas do século XIX, inicialmente com a produção de corantes e medicamentos sintéticos, intensificou-se durante o século $X X$, resultando em uma multiplicidade de matérias-primas, processos e bens de consumo que impactaram, de muitas formas, a sociedade moderna (Mauskopf, 1993). Conforme recentes investigações a respeito da filosofia da química vêm mostrando, a química apresenta algumas características peculiares que a diferenciam de outros ramos da ciência (Schummer, 2008; Baird et al., 2006), com implicações para a prática dos químicos profissionais e para suas relações com a sociedade. A química é a ciência que estuda as substâncias, a estrutura e propriedades da matéria, as interações e transformações que ocorrem na 
Natureza, mas que especialmente se ocupa de produzir novas substâncias e materiais (Schummer, 2008).

A atual pesquisa científica possui características próprias resultantes de um processo histórico longo, demorado e denso. O estudante ou leitor moderno pode não compreender a importância de cada passo dado pela ciência química, ou as mudanças de paradigmas para tentar compreender a Natureza, que resultaram em diversas e complexas ideias e linhas de pensamento, conforme as necessidades e os valores das várias épocas e locais. As transformações dos referenciais teóricos e das técnicas de análise foram ocorrendo gradativamente: das técnicas clássicas por vias seca e úmida às técnicas instrumentais, da concepção de "quatro elementos" (terra, água, ar e fogo) ao conceito moderno de elementos químicos e à tabela periódica, dos estudos qualitativos à matematização, do empirismo à experimentação moderna, são uns poucos exemplos dessas profundas transformações (Sicca e Gonçalves, 2002).

Para se compreender a importância da química dentro da sociedade é preciso levar em consideração os caminhos percorridos historicamente por essa ciência - não como enumeração de fatos históricos, mas como um processo que conduziu ao atual papel da química na sociedade, no estágio em que se encontra atualmente. Pode-se observar correlações entre o desenvolvimento científico e tecnológico da química e suas relações com a sociedade, como no período da Segunda Guerra Mundial, no qual houve grandes avanços tecnológicos, abrangendo especialmente a química, a física e a engenharia. A partir desse período, a sociedade experimentou mudanças profundas nos padrões de comportamento e de vida: nas telecomunicações, na agricultura, na estética, entre muitas outras atividades. A sociedade passou a pedir por mais avanços na ciência 
que resultassem em bens para uso pessoal. Observa-se isso atualmente, em especial, nas áreas de tecnologia da informação e de cosmética. Por um lado, tem-se a sociedade requerendo mais avanços e melhorias; por outro lado, temos a ciência se apoiando na sociedade, requerendo financiamentos para o desenvolvimento de pesquisas nas instituições públicas de pesquisa ou, no caso das empresas, desenvolvendo seus produtos dentro de limites que deveriam ser colocados pela responsabilidade social. A relação entre química e sociedade é observada inicialmente dentro das universidades, os pontos de intersecção entre o mercado profissional e o meio acadêmico.

Pierre Laszlo (2006) discorre sobre essa relação entre o "grupo de produção de conhecimentos" e a "cultura que prevalece", principalmente sobre a imagem da química percebida pela sociedade, mencionando a forte ligação entre as pesquisas acadêmicas e a expansão da indústria química. Porém, os químicos foram associados aos problemas gerados pela indústria, além de tensões políticas no período da guerra. Esse autor, assim como Jesper Sjöström (2007), acredita que se desenvolveu uma "quimiofobia" (chemophobia) por parte da sociedade em relação aos químicos, mais ou menos generalizada a partir das décadas de 1970-1980.

Para Laszlo, uma parcela significativa da população vê os químicos como que reunidos em um "gueto", sendo os bodes expiatórios da culpa pela poluição do ambiente, acusados inclusive por indústrias de outros ramos de atividades e por parte do público, a quem também cabem parcelas de responsabilidade pelas questões ambientais. Essa situação levou a comunidade química a idealizar uma "equanimidade estoica", almejando alcançar uma inabalável e pragmática ética e virtude. Essas críticas não somente levaram a comunidade química a se unir 
fortemente, como também fizeram com que enfatizassem sua autoimagem como provedores dos bens materiais à sociedade. Obviamente, como toda mudança, houve tensões, especialmente entre os mais tradicionais e os químicos mais jovens. Um dos espaços institucionais onde se manifestou e onde se refletiu a respeito dessas tensões foram as Universidades, nas quais ocorre a formação inicial dos químicos profissionais. Sjöström (2007) afirma que, entre outras funções, a formação acadêmica possibilita incentivar inovações, despertar o interesse pela pesquisa entre os alunos, e também pelas atribuições que são características da engenharia no âmbito da indústria. Sjöström (2007) sugere, ainda, algumas disciplinas que deveriam ser acrescentadas à grade curricular de química no sentido de adequar a formação dos profissionais de química às demandas dos tempos atuais. Tais sugestões serão detalhadas mais adiante.

Schummer (2008) critica fortemente a compartimentação da química em muitas disciplinas, pois acredita que esse processo resulta em uma perda de conhecimento muito substancial, a ser combatida por concepções curriculares mais holísticas e abrangentes.

Tecnicamente, o livro didático se constitui em veículo privilegiado para a comunidade química projetar as visões que considera adequadas para serem assimiladas pela sociedade a respeito da química. Historicamente, o livro didático tem sido visto como a fonte de informação mais confiável e símbolo do compêndio dos conhecimentos no âmbito acadêmico. Apesar do fácil acesso ao conhecimento que a Internet possibilita na atualidade, aliada à mobilidade e rapidez do tráfego de informações, muitas vezes é impraticável o rastreamento da confiabilidade, atualização e autenticidade dos conteúdos ali expostos. O livro didático, principalmente pela necessidade de cuidado editorial e tempo envolvidos 
em sua criação, ainda permanece como inspirador de maior qualidade e durabilidade dos conteúdos e, por sua durabilidade temporal, se constitui em um objeto de estudo adequado para analisar aspectos das relações entre a química e a sociedade.

Assim sendo, este trabalho de mestrado tem como objetivo geral investigar a imagem da química projetada por livros didáticos de química, considerando tratar-se de uma manifestação da autoimagem que os autores de livros didáticos, enquanto químicos, fazem da ciência que praticam. Para isso, foram analisados livros didáticos de química, publicados recentemente, e disponíveis na Biblioteca do Instituto de Química da Universidade de São Paulo, considerada biblioteca referência latinoamericana na área (Divisão de Biblioteca e Documentação do Conjunto das Química, s.d.). Para alcançar esse objetivo, a presente dissertação foi estruturada em quatro capítulos. No primeiro, procuramos delinear um referencial de análise, fundamentado particularmente nas tendências recentes da pesquisa em filosofia da química, que permitisse fazer considerações sobre a imagem da química e suas relações com a sociedade. No segundo capítulo, descrevemos a metodologia de pesquisa e de análise dos livros didáticos selecionados para o presente trabalho. O terceiro capítulo abrange a análise dos livros didáticos, reunindo e discutindo os resultados obtidos nessa trajetória de pesquisa. Finalmente, o último capítulo apresenta as considerações finais e algumas perspectivas abertas para futuras investigações sobre a temática aqui focalizada. 


\section{Capítulo 1: Aporte teórico}

\section{A Ciência e o cientista}

Muitas vezes, a ciência é mostrada ingenuamente nos meios de comunicação, como a resposta aos problemas da sociedade, além da visão do trabalho científico como solucionador para as dificuldades existentes atualmente nos mais diferentes âmbitos. Nesse sentido, a ciência pode exercer um efeito de entorpecimento sobre o público receptor dessas mensagens, especialmente para aqueles portadores de repertórios culturais mais limitados. Além disso, a ciência se constitui em conhecimento que confere poder a quem o detém, e parece recheada de mistérios aos olhos daqueles que não o detém. Isso é justamente o que Lazlo (2006) discute: a sociedade vê os cientistas como pessoas à parte na sociedade, ainda que não marginalizadas, pois, ao contrário, constituem uma elite intelectual. Entretanto, os cientistas seriam vistos como pessoas fechadas entre si, inalcançáveis, constituindo grupos restritos que se comunicariam em uma 
linguagem estranha aos leigos, e com conhecimento avançado e ininteligível sobre a Natureza.

A ciência é uma busca por conhecimento e entendimento da Natureza e suas manifestações, resultando naquilo que o físico e filósofo da ciência John Ziman (1925 - 2005) chamou de "conhecimento confiável". Além disso, a ciência busca também aplicações que se direcionam a produtos e inventos úteis ao dia-adia da sociedade, visando idealmente tornar nosso modo de viver mais confortável e em harmonia com o ambiente (Ziman apud Kovac, 2004). Essa busca seria motivada inicialmente pela curiosidade, embora o aspecto empírico confira ao conhecimento científico uma característica marcante de trabalho árduo e demorado, almejando resultados que sejam considerados confiáveis. Isso muitas vezes obriga os cientistas a se restringirem aos aspectos mais técnicos de seu trabalho, limitando assim o "fazer ciência" a um ideal de objetividade e precisão.

Para Ziman (1979), a ciência é produto da mente humana, perfazendo a porção intelectual do ser humano em conjunto com "a Religião, a Arte, a Poesia, o Direito, a Filosofia, a Tecnologia, etc." (Ziman, 1979). Para Ziman, todas essas manifestações compõem o conhecimento humano, sendo que, por vezes, ocorrem sobreposições entre elas. Ou seja, o que caracteriza cada um desses ramos da cultura nem sempre pode ser definido de maneira absoluta. Entretanto, muitas vezes a ciência é entendida apenas em seus aspectos mais técnicos e internos, deixando-se de lado suas implicações sobre outros aspectos da cultura.

Uma crença disseminada pela sociedade, e até entre alguns cientistas, é a de que a ciência utiliza o método científico como meio para alcançar a verdade. Porém, como observou Ziman, "Muitos filósofos têm chegado à melancólica 
conclusão de que não existe nenhum processo infalível para se erradicar de maneira definitiva o último resquício de dúvida daquilo que os cientistas chamam de conhecimento" (Ziman, 1979). Ou seja, só é possível alcançar verdades incompletas, por mais rigoroso que seja o estudo científico. Ziman sugere que os estudantes deveriam aprender Filosofia da Ciência, embora, em geral, haja certa relutância, por parte dos estudantes de ciências, para entrar em contato com o assunto. Isso poderia ajudar a formar cientistas mais bem qualificados em relação a sua própria atividade profissional, no sentido de lhes instrumentalizar para realizarem reflexões de natureza metacientífica.

Não existe uma maneira pré-determinada para a prática da ciência. Com efeito, a ciência existe na mente do cientista. Ela possibilita encontrar uma ordem, uma organização, dentro do aparente caos que a Natureza pode se apresentar aos olhos do observador. Todo aquele que faz ciência é um cientista. Ser cientista não é uma condição, é um estado. Todo cientista cria ideias originais sobre a Natureza, baseadas em algo empírico. Nas palavras de Ziman,

o objetivo da Ciência não é apenas adquirir informação (...), é alcançar um consenso de opinião racional que abranja o mais vasto campo possível (Ziman, 1979).

O Fazer-Ciência, para Bronowski (1956), faz parte de um ato de criatividade, cuja essência está na descoberta de semelhanças e classificações ocultas dentro da própria Natureza.

Segundo o guia On Being a Scientist (2009), um manual de conduta para a pesquisa científica, editado pela National Academy of Sciences, National Academy of Engineering e Institute of Medicine dos EUA, o pesquisador possui três motivações para se manter aderido ao fazer-ciência, a saber: i) os 
pesquisadores possuem obrigações para com seus colegas, mantendo a honra e a verdade; ii) os pesquisadores possuem um contrato consigo próprios; iii) os pesquisadores devem agir em benefício do público (National Academies, 2009). Para citar um exemplo, muitas pesquisas científicas são financiadas com verbas públicas; logo, seria justo que o pesquisador, financiado por dinheiro público, se preocupasse em proporcionar benefícios à sociedade como contrapartida pelo investimento realizado. Por outro lado, um pesquisador financiado por uma empresa privada teria o imperativo ético de não permitir que a busca do lucro para seu empregador se desse em prejuízo da sociedade de maneira mais ampla.

Até este ponto, falamos sobre o pesquisador, o cientista, inclusive estudantes de ciências que serão os futuros pesquisadores da área. Mas qual seria a diferença entre o cientista químico e o profissional químico? Em suma, o cientista químico é o pesquisador acadêmico e o profissional químico é o químico voltado diretamente para o mercado, para o meio produtivo, que pode abranger empresas do setor industrial e do setor de serviços, como vendedores técnicos, por exemplo. Para aprofundar esse questionamento, é necessário avançar para além das definições, mas entender o surgimento dessas diferenciações. Mary Jo Nye (1993) afirma que, diferentemente dos físicos, os químicos buscam a multifuncionalidade das moléculas, pelas propriedades e capacidade de gerarem novos objetos - ou seja, a produção de novas moléculas implica em novas entidades para estudo e também novas substâncias, com potenciais aplicações úteis e também oferecendo potenciais riscos. Por conta disso, Sjöström (2007) acredita que a química é simultaneamente ciência e tecnologia. As tecnologias químicas criadas e aplicadas em laboratório fazem com que, em uma escala mais ampla do que outras ciências da Natureza, a química busque mais que 
explicações para a realidade que nos cerca: de certa forma, os químicos querem "mudar o mundo". Schummer (2001) utiliza o termo "química sintética” para caracterizar um conjunto de atividades desenvolvidas por químicos em laboratórios cujos produtos ultrapassam o plano das ideias, mas se materializam em novas substâncias que mudam o mundo ao redor, para melhor ou para pior. As consequências positivas e negativas dos desenvolvimentos tecnológicos proporcionados pelos químicos ao longo do tempo foram moldando as relações entre a química e a sociedade.

Devido a sua natureza prática, a química está ligada fortemente à industria. Kovac (2004) argumenta que os químicos têm uma relação com a experimentação mais próxima e intensa do que os físicos: "os químicos precisam 'pensar com as mãos' mais do que outros cientistas” (p. 164, tradução nossa). Como a química tem a própria indústria, diferente das outras ciências da Natureza, como a física, a biologia ou a geologia, Laszlo (2006) afirma que a autoimagem do químico profissional foi assentada sobre as bases de uma relação direta com a indústria. Do ponto de vista de Laszlo (2006), a química acadêmica e a química industrial dividem um "cordão umbilical". Esse autor destaca um aspecto fundamental nessa relação: as universidades formam químicos para carreiras na indústria e, em retorno, a indústria química financia áreas de pesquisa e desenvolvimento dentro das universidades, o que resulta em um usual intercâmbio de cientistas entre as instituições acadêmicas e a indústria.

Conforme foi mencionado acima, esse acentuado caráter aplicado da química resulta em aspectos benéficos, mas também maléficos, para a vida das pessoas - impactando diretamente sobre a imagem que a química projeta sobre a sociedade. 


\section{A imagem da química na sociedade}

As profissões científicas e o fazer-ciência foram adquirindo as características que exibem atualmente devido a um processo histórico percorrido por elas, no qual se desenvolveram e se assentaram na sociedade - e a como a sociedade, reciprocamente, se adaptou. No âmbito histórico, de acordo com Russell e Roberts (2006), a química gerou um verdadeiro impacto em escala global a partir da metade do século XVIII, quando a sociedade europeia estava no auge do lluminismo. Nessa época, aumentava significativamente a demanda por produtos como ácido sulfúrico, principalmente para a fabricação de soda (carbonato de sódio, ou barrilha), o que fez esse ácido ser considerado por Liebig como um produto comercialmente atrativo. Técnicas melhores e mais eficientes para a fabricação de determinados produtos foram sendo desenvolvidas, gerando também subprodutos de interesse comercial, aumentando a demanda industrial. A indústria precisava aumentar sua escala de produção, não apenas de ácido sulfúrico, mas de muitos outros produtos, o que fez crescer também a demanda por fontes de energia. Esse processo aumentou a oferta de empregos nas cidades, e causou mudanças demográficas, com a formação de polos urbanizados. Juntamente com o aumento do trânsito de trabalhadores e seus familiares, e do transporte de produtos, ocorreu o desenvolvimento do transporte de massas, com as ferrovias. Sobre esse período, o historiador da química, Collin Russell, observou:

O fato é que a recente pesquisa acadêmica demonstrou (...) que a Química não foi meramente um determinante 
importante, mas um componente crítico do surgimento de uma sociedade industrial (Russell, 2004, p. 366, grifo nosso).

Não somente os setores produtivos ligados aos motores e transportes evoluíram, mas também a produção têxtil. Quanto mais a população crescia, maiores eram as demandas, não somente em quantidade, mas em rapidez, por mais produtos prontos, colocados no mercado mais rapidamente, com materiais mais baratos e de fácil ou simples obtenção. Russell (2004) cita a importância do método Leblanc para a produção de soda (carbonato de sódio), permitindo a produção de sabão de sódio em larga escala, o que era demandado pela crescente indústria têxtil. O aumento de escala da produção de soda, por sua vez, foi possibilitado pelo crescimento da produção de ácido sulfúrico, especialmente graças ao método das câmaras de chumbo - pois a primeira etapa do processo Leblanc consistia na reação química entre ácido sulfúrico e cloreto de sódio para a produção de sulfato de sódio.

Outro desenvolvimento da química, fundamental para a indústria têxtil nesse período, foram os alvejantes obtidos a partir do cloro. Muitos outros produtos e processos químicos que impactaram fortemente a sociedade entre os séculos XVIII e XX são citados por Russell (2004), tais como o uso de fosfatos como fertilizantes, a produção de explosivos nitrogenados, os corantes sintéticos, a análise da potabilidade da água, o tratamento de água para consumo, os inseticidas sintéticos, os analgésicos, os anestésicos, os antibióticos, a síntese artificial da amônia, etc.

Apesar dos muitos aspectos positivos trazidos pelos desenvolvimentos da química, é preciso considerar também que uma série de aspectos negativos estiveram associados a eles, especialmente a poluição no entorno das indústrias 
químicas, cujas instalações foram adquirindo proporções cada vez maiores. Assim, Russell (2004) argumenta que a química alternou momentos em que a opinião pública foi indiferente, desfavorável ou favorável a ela. Citando a Inglaterra como exemplo, Russell (2004) aponta que a química atingiu uma imagem muito desfavorável no início do século XIX, devido à terrível poluição gerada pelas indústrias de álcalis (que lançavam cloreto de hidrogênio, então um subproduto indesejável, na atmosfera), por exemplo. Entretanto, a imagem da química naquele país melhorou após a aprovação de leis, na segunda metade do século XIX, que obrigavam as indústrias a controlarem suas emissões de poluentes. Outro fator que pesou de maneira favorável foi a profissionalização da atividade química, com a criação de um instituto que congregava os profissionais da área, permitindo maior controle sobre sua atuação. Essa instituição foi também responsável pela divulgação para o público leigo, na forma de livros e outras publicações, dos benefícios trazidos pelas pesquisas e aplicações da química, que se multiplicavam nas primeiras décadas do século XX.

Segundo Russell (2004), a imagem pública da química voltaria a piorar na década de 1960, época em que surgiu o movimento "ecológico", depois chamado ambientalista. Um marco importante desse período foi a publicação do livro de Rachel Carson, Silent Spring (1962), que denunciava os danos ambientais causados pelo uso em grande escala do inseticida DDT. Outros casos de poluição, de efeitos colaterais de produtos químicos lançados no ambiente, e de acidentes em instalações industriais, ao longo dos anos 1960, 70 e 80, contribuíram para que a imagem pública da química chegasse ao final do século XX extremamente desgastada. A tal ponto chegou a aversão da sociedade pela química, que muitas empresas e departamentos de química de universidades e 
instituições de pesquisa mudaram seus nomes, retirando a palavra "química" e suas derivadas, substituindo-as por novos termos, como "ciência de superfícies", "nanociência”, "nanotecnologia”, "ciência dos materiais”, etc. (Laszlo, 2006). O químico I. Horváth, então editor do periódico Accounts of Chemical Research, contou, de maneira bem humorada, que passou a ser visto com simpatia por leigos quando deixou de se apresentar como químico, passando a autodenominar-se “designer de moléculas” (Horváth, 2002).

A trajetória da química nos últimos séculos incluiu a produção de bens que trouxeram conforto e bem estar para um número significativo de pessoas, mas também teve consequências como poluição, doenças e a degradação do ambiente. Assim, essa trajetória gerou, em diferentes momentos, mudanças favoráveis e altamente desfavoráveis para a imagem da química e dos químicos. Um fator chave para a formação dessa opinião pública foram os meios de comunicação de massas (Laszlo, 2006) que deram grande repercussão, em especial, às polêmicas envolvendo as indústrias químicas. Um exemplo disso pode ser encontrado ao se observar a complexa questão energética na segunda metade do século $X X$.

Na década de 1970 houve a crise do petróleo, ocasião em que o grande aumento do preço dessa commodity, em ação conjunta da Organização dos Países Exportadores de Petróleo (OPEP), provocou profundos impactos sobre a economia mundial. A indústria química dispendeu grandes esforços em busca de alternativas para diminuir custos, aumentar a eficiência de seus processos e encontrar substitutos para os derivados do petróleo. No Brasil, em 1975, foi criado o Programa Nacional do Álcool (Proálcool), buscando diminuir a dependência em relação ao petróleo importado, que representava cerca de $80 \%$ do petróleo 
consumido no país. O Proálcool incentivou o uso do etanol, produzido em abundância no Brasil a partir da cana-de-açúcar, como combustível em automóveis. Essa busca por alternativas energéticas e de matérias-primas também gerou preocupações relacionadas à questão ambiental. Nas décadas finais do século $X X$, houve diversos acidentes com navios petroleiros, gerando grandes prejuízos ambientais. A cobertura da mídia fez gerar desconfianças com relação à atuação dos profissionais químicos em geral, não apenas contra a indústria química, atribuindo-Ihes erros por negligência e responsabilizando-os por acidentes ocorridos. Ou seja, a mídia teve papel fundamental na formação da imagem pública da química perante a sociedade (Laszlo, 2006). Muitos aspectos dessa imagem estão relacionados a questões de natureza ética - uma temática particularmente sensível quando se trata da atividade química, conforme se verá a seguir.

\section{A ética dentro da química}

A ética é uma ampla área do conhecimento que pode ser considerada como um ramo da filosofia, com implicações e interfaces que se espraiam por diversos ramos do saber. Segundo Rios (1993), a ética (do grego ethos) e a moral (do latim mores) são palavras que tiveram seus significados miscigenados, ambas significando, originariamente, costume. Sendo assim, há uma relação com a cultura na qual o indivíduo está inserido, sendo a ética fundamentada na cultura a sua volta. A cultura é a maior marca da evolução humana: todos os seres vivos levaram milênios para evoluírem geneticamente, mas os seres humanos utilizaram de suas criações/ferramentas e transmitiram seu conhecimento e seu 
manejo para as gerações seguintes. O mesmo se aplica, de forma mais ampla, à própria cultura: não existe cultura na Natureza, há apenas instintos de sociedade e coletividade, como acontece com formigas e abelhas, por exemplo.

Rios observa que a ética "se apresenta como uma reflexão crítica sobre a moralidade, sobre a dimensão moral do comportamento do homem" (Rios, 1993). Segundo a autora, a ética como filosofia permeia os valores, procurando problematizá-los e procurando a melhor ação a tomar, constituindo um juízo crítico. Nesse aspecto, a ética se diferencia da moral. Vázquez (1975) explica que a ética e a moral são características unicamente humanas, adquiridas e conquistadas através do hábito (cultura). A ética, por um lado, precisa ser rigorosa, coerente e bem fundamentada. A moral, por sua vez, pode ser normatizada em um conjunto de regras; com efeito, ela se transforma em objeto de estudo científico, diferentemente da ética, que já apresenta em seu âmago o rigor do científico. Portanto, a moral explicita o que é bom e ruim numa sociedade, e a ética "procura o fundamento do valor que norteia o comportamento, partindo da historicidade presente nos valores" (Rios, 1993).

Kovac (1996), um especialista contemporâneo em ética química, introduz a temática observando que o termo "ética" tem pelo menos três significados diferentes. O primeiro seria um significado cotidiano, que seriam valores, padrões e condutas que se deseja de uma sociedade. O segundo seria a acepção filosófica, tendo a teoria ética como eixo, a qual estuda os valores e padrões humanos dentro das condições sociais e individuais. O terceiro significado seria a ética na profissão, envolvendo códigos de conduta formais e/ou informais. Ou seja, trata-se de um mecanismo de condutas e eventos articulados entre si, e que 
geram ações e reações futuras. A ética profissional está intrinsecamente ligada ao profissionalismo.

Kovac (1996) explica que, nos Estados Unidos, existe a American Chemical Society, que oferece um certificado aos estudantes graduados em química, por meio de um comitê responsável, para o exercício da profissão. Ainda assim, naquele país não é um pré-requisito ter um diploma de bacharel para exercer a função de químico. No Brasil, existem os Conselhos Regionais de Química (CRQ) e o Conselho Federal de Química (CFQ), que regulamentam as várias atribuições relativas à profissão de químico e seu exercício. Sem o devido registro nessas entidades, o estudante formado, seja em cursos de nível médio, tecnológico ou superior, não pode exercer suas atividades como químico em empresas ou mesmo em certas instâncias do magistério.

Segundo Schummer,

seria errado desconsiderar a incorporação cultural específica da química de um ponto de vista filosófico, porque isso moldou essencialmente a visão ética da química (Schummer, 2008, tradução nossa).

Por exemplo, a indústria química não é neutra, pois a produção envolve interesses, especialmente econômicos. A forma como o conhecimento é produzido e aplicado influencia o desempenho ético dos químicos na indústria e na pesquisa, numa relação que também é recíproca.

Esse desempenho ético é também refletido na educação. Conciliar a ética com o ensino de Ciências, propiciando ao educando possibilidades e autonomia para aplicar o que aprendeu, se constitui em um grande desafio para os formadores. Isso não significa, por exemplo, simplesmente apresentar aos alunos 
a ideia de que a prática de plágio, seja de relatórios, trabalhos escolares e acadêmicos, ou mesmo de trabalhos de pesquisa, se constitua em procedimento errado. A inserção e a compreensão da ética no ensino se dão por meio das próprias ações dos professores, dos conteúdos explícitos e ocultos nos materiais didáticos, e do próprio currículo.

No ensino de humanidades, como a história, por exemplo, é mais fácil detectar questões de natureza ética, pelas tendências do professor ou da instituição de ensino, que podem induzir o educando a determinados comportamentos. Uma situação exemplo ocorre em época de eleições, quando os alunos do ensino médio querem saber em qual candidato o professor vai votar. Não é tarefa simples responder a essa pergunta de maneira adequada, considerando o quanto os alunos, nessa faixa etária, são influenciáveis pelas opiniões do professor. No ensino de Ciências, porém, é mais difícil identificar questões de natureza ética, pois podem não estar ligadas às opiniões pessoais do professor, mas sim, a aspectos mais amplos, como à própria concepção de currículo.

Ou seja, o conhecimento que se apresenta nas aulas seguindo o currículo deve contribuir para que o aluno, já no ensino médio, forme suas próprias opiniões, "com fundamentos acerca de questões bastante polêmicas e [possa] orientar suas ações de forma mais consciente" (Brasil, 1998). O professor deverá se basear em fatos científicos, como, por exemplo, no contexto de uma discussão sobre o destino dado ao lixo industrial. Neste caso particular, será relevante para as reflexões do aluno o quanto ele tem de conhecimento e vivência a respeito do assunto, seja por ser um trabalhador da indústria, o filho de um empresário do ramo, ou simplesmente um cidadão que acompanha a questão através dos meios 
de comunicação de massas. O professor universitário pode encontrar todos esses tipos de alunos em suas turmas de graduação e terá, na condição de mediador, que administrar opiniões polêmicas e muitas vezes opostas, sendo necessário observar a qualidade dos argumentos. Mas, quais critérios os educadores em química devem usar para avaliar a qualidade desses argumentos, além dos fatos científicos?

Para Kovac (1996), são dois os objetivos principais que justificam a inserção da ética da ciência no ensino. O primeiro objetivo está voltado a ensinar os alunos a reconhecer e analisar questões éticas, isto é, propiciar aos alunos o ganho de experiência para identificar esses questionamentos. O segundo objetivo se refere à avaliação das diversas possibilidades de ação em cada caso, e à escolha, entre as possíveis condutas, qual será a mais adequada na respectiva situação. Esses objetivos estão voltados para que o aluno aprenda a repensar as ações e a escolher, dentre elas, a que trará as menores consequências negativas (ou mesmo nenhuma), além de exercitar a paciência e o discernimento, conceitos atitudinais necessários não somente em sala de aula ou no futuro ambiente profissional, mas em todo ambiente social, característico da vida adulta. O maior desafio para o professor de ciências talvez seja lidar com, ou evitar, os atritos que eventualmente surgem em sala de aula e tiram o foco da questão principal, que é o conhecimento científico. Assim, observa-se a necessidade de modificar os enfoques tradicionais do ensino, desde a educação básica até o ensino superior, para que seja possível a incorporação desses novos objetivos almejados pela educação no século XXI.

Kovac também apresenta a ideia de que a ética é uma parte integrante da ciência (Kovac, 2000), especialmente se esta é tratada como uma profissão. A 
ética deveria estar intrinsecamente conectada ao exercício das profissões científicas, que poderiam se inspirar nas profissões que possuem códigos de conduta e ética, sejam eles estabelecidos por conselhos profissionais, seja pela tradição, ou mesmo através de leis. Idealmente, as reflexões de caráter ético, e seu melhor exercício, surgiriam espontaneamente no comportamento do indivíduo, mas isso pode não ocorrer. As implicações são sérias, pois as profissões científicas têm relação muito estreita com a sociedade, e têm potencial para causar impactos profundos. Por um lado, a sociedade pede um serviço ou produto; por outro lado, os cientistas oferecem a garantia e confiabilidade desse serviço ou produto. Essa demanda está cada vez maior e mais competitiva, exigindo produtos cada vez melhores, que atendam ao mercado o quanto antes.

Outro questionamento relevante é que os profissionais precisariam entender que cada cientista é dependente da sociedade em geral para criar a ciência, e isso leva a uma relação desigual, na qual um se transforma em especialista e os outros se transformam em leigos ${ }^{1}$, cada um tendo suas incumbências éticas, seja para o especialista ter cuidado com o que divulga, seja para o leigo ter cuidado com as informações que recebe (Kovac, 2000). Fora da ciência, essa situação é muito comum, como no exemplo cotidiano das emissoras de televisão, que deveriam zelar por aquilo que transmitem, enquanto os espectadores deveriam ter mais critério ao escolher a que assistem. A condição de especialista acarreta uma confiança social, isto é, a sociedade passa a confiar no cientista e, consequentemente, na ciência. Nas palavras de Kovac (2004),

\footnotetext{
${ }^{1}$ O termo desigual não está em um sentido maniqueísta, mas aponta para algo que ocorre naturalmente em uma sociedade, não havendo juízo de valor, apenas uma descrição factual.
} 
"formalmente ou informalmente, a sociedade garante à profissão (de cientista) o monopólio em um conhecimento ou competência específicos".

Kovac (2000) sugere a inserção de cursos formais de ética como "parte integrante da educação em ciência", até mesmo como disciplinas nos cursos superiores. Essa sugestão encontra apoio nas opiniões de vários autores aqui citados, e entre outros educadores em ciências. O ensino de química foi ficando cada vez mais restrito aos conteúdos cognitivos, sendo particularmente relacionada a aspectos utilitaristas. Hoffmann (1995) afirma que os cientistas incorporaram o modo reducionista de pensar como guia ideológico; no entanto, essa filosofia é muito afastada da realidade com que os cientistas químicos de fato trabalham. Isso pode colaborar para distorcer a imagem da química diante da sociedade.

A atividade química se encontra bastante especializada, tanto para o aprofundamento das áreas, quanto para os interesses da indústria. Por um lado, isso é positivo, pois tem proporcionado um crescimento sensível de conhecimento e tecnologia. Por outro lado, isso significa também algo mais preocupante. Os racionalistas, como Schummer, têm essa preocupação, pois ao fazer a compartimentação, a química pode se descaracterizar enquanto ciência. Nesse caso, o químico teria uma formação parcial, sem ter uma visão ampla da verdadeira dimensão da química, ou seja, daquilo que perpassa todas as especialidades. O formado em química vai se preocupar mais com o avanço tecnológico do que com suas implicações culturais. Em termos de institucionalização do ensino, é preciso considerar que a universidade também precisa educar, e não proporcionar uma visão técnica-instrumental apenas. No contexto atual do ensino, os químicos, após a formação inicial, raramente 
desenvolvem um olhar crítico e ético sobre seu papel, e o da própria química, dentro da sociedade em que vão atuar (Sjöstrom, 2007; Schummer, 2008).

Ainda acerca do ensino de química, tanto Schummer (2008) como Sjöström (2007) abordam o pluralismo metodológico no âmbito da química. Esse pluralismo é influenciado por determinados estilos epistemológicos aplicados à química, abrangendo uma variedade grande de temas (ou interesses) que se refletem nas publicações, não apenas acadêmicas, mas também didáticas, como os livros-textos. Sjöström (2007) sugere a inclusão, nos cursos de formação inicial, de disciplinas cujos conteúdos abrangeriam o que ele denomina de "metaquímica", a saber: Filosofia da Química, Educação Química, História da Química, Química e Sociedade, Química Verde. Sjöström (2007) sugere também que o processo de formação de um químico não deveria ser caracterizado apenas como "educação", mas como Bildung², fundamentado sobre três aspectos: (1) visão holista, que é sobre a inteligência no espaço, tempo e cultura como o mínimo necessário para entender o mundo; (2) sabedoria, abrangendo uma visão crítica do indivíduo como pensante e integrante de um coletivo, uma maturidade diante de valores e conhecimentos científicos; (3) phtonesis, a habilidade de colocar em prática a própria ideologia em ações responsáveis, uma sabedoria aplicada ou prática.

\footnotetext{
2 Bildung é um termo alemão, que se refere a um "auto-crescimento" do indivíduo, voltado a um aspecto mais filosófico para o crescimento/agregação pessoal e cultural, o que inclui a profissão.
} 


\section{O livro didático}

De acordo com os Parâmetros Curriculares Nacionais (Brasil, 1998), é na escola que o aluno aprende conceitos de justiça, respeito e solidariedade, sendo uma preparação para o futuro exercício da cidadania. "A escola deve ser um lugar onde os valores morais são pensados, refletidos, e não meramente impostos ou frutos do hábito" (Brasil, 1998). Isto é, não se desenvolve a ética "por imitação, osmose ou transversalidade", mas pela reflexão sobre o atual modo de vida (Severino, 2010).

Como não existe educação imparcial, a própria escola, juntamente com outras instituições sociais, se encarrega de ensinar princípios morais e éticos às crianças e jovens. Esses conceitos são transmitidos, intencionalmente ou não, por meio dos colegas, dos professores, dos livros didáticos, da Internet, das redes sociais, etc. Não é possível ensinar valores sem dar o mínimo de contextualização. De certa forma, o professor acabará sendo também um educador da moral, daí a importância da reflexão sobre a ética durante sua formação, como um tema transversal no ensino superior (Rios, 2010). Krasilchik (1988) também aborda essa questão, argumentando que o professor conseguirá formar cidadãos autônomos sem recorrer a posturas autoritárias, e apresentando os conflitos sem filtros ou censuras. De maneira ética, o professor não estará "doutrinando", mas ensinando.

Os PCNs de Ciências da Natureza enfatizam a importância de o professor trabalhar com projetos, que propiciam o trabalho em equipe, bem como a articulação entre os diversos conteúdos de Ciências Naturais e os temas transversais, como a ética. A tecnologia, segundo os PCNs, é um bom tema para 
a abordagem inicial de questões éticas, estando intrinsecamente ligada a outro tema transversal, que é o ambiente. A ética está ligada a assuntos políticos e econômicos; ao trazer esse questionamento para a sala de aula, o professor pode problematizar a visão ingênua de que o desenvolvimento tecnológico é sinônimo de crescimento social e de "conforto individual" (Brasil, 1998).

As Diretrizes Curriculares Nacionais para a Formação de Professores da Educação Básica (Brasil, 2001) explicitam a importância de uma formação de qualidade do docente. Após a democratização do acesso e o aperfeiçoamento da educação básica, o Brasil passou por diversas mudanças nas demandas sócioeducacionais. Não obstante, o mercado demanda profissionais cada vez mais qualificados. Os resultados são claros:

Quanto mais o Brasil consolida as instituições políticas democráticas (...), mais se amplia o reconhecimento da importância da educação para a promoção do desenvolvimento sustentável e para a superação das desigualdades sociais (Brasil, 2001).

Segundo Souza, Mate e Porto (2011), o livro didático é muitas vezes visto como o portador de um conhecimento "canônico", sem aberturas para questionamentos, limitando a liberdade de pensamento dos educandos e dos educadores. Para Nascimento, Macedo e Oliveira (2011), apesar dos avanços, o livro didático ainda é o recurso mais utilizado dentro da sala de aula, devendo oferecer oportunidades aos educandos para reflexões aprofundadas para a vida em sociedade.

O livro didático é geralmente alvo de discussões sobre a adequação ou inadequação dos mesmos, sendo responsabilizado muitas vezes por fracassos 
escolares. A questão não é condená-los, mas identificar aspectos que possam prejudicar a aprendizagem e desenvolver formas de superar eventuais problemas no contexto da sala de aula. Para isso, é necessário um currículo bem arquitetado e um docente bem formado, capaz de exercer sua capacidade crítica e sua autonomia.

Muitos autores já fizeram trabalhos sobre livros didáticos, apontando suas deficiências e possíveis soluções para os problemas (Neto e Fracalanza, 2003). Entretanto, há muitas abordagens que ainda podem ser exploradas para a análise de livros didáticos. A discussão sobre a avaliação de livros didáticos é importante para aprimorar competências e habilidades no contexto da formação de professores. Lopes (2007) vai além, e questiona sobre o "didático" em relação ao livro escolar, sugerindo até mesmo a retirada do adjetivo. Essa mudança "traria também um outro lugar às práticas pedagógicas, aos saberes docentes, e às relações entre professores e estudantes" (Lopes, 2007).

No Brasil, a Resolução n 60, de 20 de novembro de 2009, dispõe sobre 0 Programa Nacional do Livro Didático (PNLD) para a educação básica (ensino fundamental e médio). Essa resolução está fundamentada na Constituição Federal, artigos 205, 206, 208, 211, e 213; nas Leis nos $^{\mathrm{s}} 8.666$, de 21 de junho de 1993; 9.394 - LDB, de 20 de dezembro de 1996; 10.172, de 9 de janeiro de 2001; e 10.406, de 10 de janeiro de 2002; e nos Decretos nos 99.658 , de 30 de outubro de 1990, e 6.583, de 29 de setembro de 2008 (Brasil, 2009). No entanto, o único instrumento legal que mencionou o livro didático para o ensino superior foi o decreto-lei 1006 de 30 de novembro de 1938, em seu parágrafo único:

Os livros didáticos próprios do ensino superior independem da autorização de que trata este artigo, nem estão sujeitos 
às demais determinações da presente lei, mas é dever dos professores orientar os alunos, a fim de que escolham as boas obras, e não se utilizem das que Ihes possam ser perniciosas à formação da cultura (Brasil, 1938).

Desde então, o livro didático para o ensino superior não mais foi mencionado por qualquer lei brasileira, nem normativa, nem parecer do Conselho Nacional de Educação (CNE). Não há, pelas próprias características do ensino superior, preocupação em regulamentar a articulação do material com o currículo, como ocorre na educação básica, na qual os livros didáticos são elaborados a partir do currículo e passam pelo crivo do MEC antes de serem adotados pelo PNLD.

No caso da química, e relembrando o que Sjöström (2007) sugeriu como ensino objetivando o Bildung, que está mais relacionado a um conhecimento voltado aos valores e qualidade, há possibilidade de reflexões mais críticas a respeito de questões importantes no que tange à sociedade. Essas questões sociais podem ser discutidas, no contexto do ensino, por meio de abordagens interdisciplinares envolvendo ciência e sociedade. De fato, para englobar essas áreas, é necessário ter perspectivas e raciocínio crítico tanto acerca da área de ciências quanto da área de humanidades. Nesse ponto se observa a importância da educação e dos materiais didáticos. Zoller (2004) afirma que está ocorrendo um processo de transformação da especialização e compartimentação das ciências para uma concentração multidimensional do conhecimento, sem delimitações entre as interfaces da ciência, tecnologia, ambiente e sociedade. Quanto maior o trânsito dos educadores por entre os conhecimentos dessas diversas áreas, mais enriquecedoras serão as abordagens didáticas para as 
questões sócio-científicas, e mais elaboradas poderão ser as reflexões dos estudantes em termos de pensamentos críticos e ideológicos.

Nesse contexto, se justifica o interesse pela investigação dos conteúdos dos livros didáticos de química. Se ainda parece distante o ideal de formação de químicos delineado por Sjöström (2007) - de acordo com o qual os conteúdos dos livros didáticos exerceriam uma função de ponte de integração da química com outras áreas, bem como com questões sociais mais amplas - é relevante voltar nosso olhar para os livros didáticos de química da atualidade, a fim de caracterizar em que medida alguns aspectos desse ideal podem estar sendo aproximados, ou o quão distantes ainda estão em relação a ele. Tendo isso em vista, o próximo capítulo delineia a metodologia usada em nossa investigação. 


\section{Capítulo 2: Percurso Metodológico}

Para a realização deste trabalho, fez-se inicialmente um levantamento bibliográfico sobre a temática da relação química-sociedade, em especial no que tange à imagem da química perante a sociedade. Em seguida, foi feito um levantamento a respeito de investigações sobre livros didáticos, focalizando nos livros de química. O passo seguinte foi definir critérios para a seleção dos livros didáticos a serem analisados.

Inicialmente, pensamos em selecionar para análise os livros de química geral mais procurados pelos frequentadores da Biblioteca do Conjunto das Químicas (BCQ) da Universidade de São Paulo (Campus Butantã, São Paulo, $\mathrm{SP})$, considerada a principal do país na área de química. Foi encaminhada uma solicitação à $\mathrm{BCQ}$ para que enviasse uma relação dos livros mais retirados nos últimos dois anos, tendo em mente que poderíamos assim obter um perfil dos livros mais utilizados pelos estudantes de química em sua formação inicial. Ao examinar a lista de livros fornecida pela BCQ, constatamos que essa não foi uma decisão acertada, pois a biblioteca é frequentada por alunos de diversas carreiras 
diferentes: química, farmácia, engenharia química, geologia, além de muitos outros cursos que têm aulas de química e bioquímica no IQ-USP, sem contar a diversidade de alunos da pós-graduação. Isso se refletiu na variedade dos títulos que constam da lista, não relacionados aos interesses desta investigação. A lista fornecida pela BCQ é apresentada no Quadro 1.

\begin{tabular}{ll}
\hline \multicolumn{1}{c}{ Título } & \multicolumn{1}{c}{ Autor } \\
\hline Álgebra linear com aplicações & Anton \\
Álgebra linear contemporânea & Anton \\
Um curso de cálculo & Guidorizzi \\
Cálculo & Stewart \\
Fundamentos de física & Halliday \\
Física & Tipler \\
Química ambiental & Baird \\
Química ambiental & Spiro \\
Princípios de química & Atkins \\
Química: a matéria e suas transformações & Brady \\
Química: a ciência central & Brown \\
Química geral & Chang \\
Química geral e reações químicas & Kotz \\
Quantum chemistry & McQuarrie \\
Físico-química & Atkins \\
\hline Físico-química & Ball \\
Eletroquímica & Brett \\
Eletroquímica & Ticianelli \\
Experiências de química & Giesbrecht \\
Fundamentos de química analítica & Skoog \\
\hline
\end{tabular}

Tabela 1: Livros mais consultados pelos frequentadores da BCQ nos anos de 20132014. 
A inadequação dessa lista aos nossos propósitos pode ser observada logo no primeiro título, que é Álgebra linear, de Anton, um livro didático da área de matemática, utilizado por estudantes de diversas carreiras.

Decidimos então modificar nosso critério para a seleção dos livros didáticos. Seguindo a metodologia utilizada por Viana (2007), buscamos localizar os livros mais recomendados para as disciplinas iniciais dos cursos de química em geral, denominadas "Química Geral”, "Química Fundamental”, ou algum nome semelhante a esses - e que fossem ministradas no primeiro semestre, ou primeiro ano de cursos de licenciatura ou bacharelado. O levantamento foi feito a partir das ementas de disciplinas de seis cursos de química de universidades brasileiras, cujas informações estão disponíveis via Internet. Foram consultados três cursos oferecidos em diferentes campi da Universidade de São Paulo (IQUSP, São Paulo; IQSC-USP, São Carlos; e DQ-FFCLRP-USP, Ribeirão Preto); cursos de três Universidades Federais de diferentes regiões (IQ-UFMG, Belo Horizonte; DQ-UFSC, Florianópolis; e IQ-UnB, Brasília); e um curso de Universidade particular (DQ-Mackenzie, São Paulo). Não houve qualquer pretensão de realizar um levantamento completo e abrangente, mas apenas de selecionar livros didáticos de química geral que venham sendo bastante indicados em disciplinas de química geral, em universidades com diferentes perfis. Como resultado desse levantamento, foram escolhidos para análise os quatro títulos mais indicados nessa amostra, listados a seguir:

- Atkins e Jones, Princípios de química: questionando a vida moderna e o meio ambiente;

- Brown, LeMay e Bursten, Química: ciência central;

- Chang, Química Geral - Conceitos essenciais; 
- Kotz e Treichel, Química e reações químicas.

Além desses, seguindo Fernandes e Porto (2012), decidimos incluir em nossa análise um quinto livro, a saber:

- Garritz e Chamizo: Química.

Esse livro não se encontra entre os mais indicados em disciplinas introdutórias do ensino superior. Entretanto, decidimos incluí-lo na análise em função da abordagem diferenciada adotada por seus autores, em comparação com os demais livros de química geral selecionados. Garritz e Chamizo (1994) incluíram em seu livro conteúdos de história da ciência e temas que relacionam o conhecimento químico com o contexto social, especialmente em relação ao contexto latinoamericano. Assim, constitui-se em material didático de particular interesse para a análise que se propõe nesta dissertação.

No que se refere aos critérios de análise de livros didáticos, primeiramente, foi necessário entender a intenção do autor com o livro. Alguns escrevem manuais que valorizam a objetividade e os procedimentos para a resolução de questões exemplares, que podem ser de importância para a formação do químico, mas que não são parte integrante do foco deste trabalho. Outros escrevem livros didáticos voltados tanto para cursos de graduação quanto de pós-graduação. Embora os livros didáticos sejam, obviamente, voltados para a formação dos alunos, cada qual pode conter aspectos diferenciados, conforme os objetivos do autor. Assim, buscamos identificar se os livros didáticos focalizam aspectos políticos, econômicos, ou aspectos tecnológicos como promotores de benefícios sociais.

Em segundo lugar, buscamos compreender qual a imagem da química projetada pelo autor. Por exemplo, se o autor caracteriza a química como uma 
ciência "pura", isolada de outras ciências, e mesmo de outras áreas do conhecimento humano; ou se a caracteriza inserida nos respectivos contextos históricos e sociais de seu desenvolvimento, explicitando relações entre a química e a sociedade. 


\section{Capítulo 3: Resultados e Discussão}

Os livros didáticos de química geral analisados atendem, de maneira ampla, ao estudante que se formará um químico para a indústria, mais do que a um futuro químico acadêmico. Um dos aspectos mais marcantes da relação entre a química e a sociedade se refere às questões ambientais, ao impacto das atividades químicas sobre os ecossistemas e sobre as populações. Tais questões, em geral, são abordadas mais particularmente em livros de química ambiental, que nem sempre integram a bibliografia dos cursos de formação inicial de químicos. Nos livros de química geral, observamos que essa temática é abordada mais superficialmente. Em todos os livros didáticos analisados foram encontradas menções a algum problema ambiental que, no entanto, são abordados como se fossem um percalço no trabalho dos químicos, algo como um acidente inevitável. Não foram encontradas discussões mais aprofundadas: quando muito, os autores apresentam sugestões ou oportunidades de discussão sobre os assuntos de natureza ambiental. Considerando que os químicos se apoiam mutuamente, conforme sugerido por Laszlo (2006), essa ausência de 
"autocrítica”, ou de críticas mais contundentes à indústria química, era esperada. Além disso, foi possível observar outro ponto de interesse, qual seja, a valorização do cientista como um transformador social.

A seguir, apresentamos a análise para cada um dos cinco livros de química geral selecionados, buscando caracterizar como apresentam a relação mútua química-sociedade.

\section{Livro 1: Atkins e Jones}

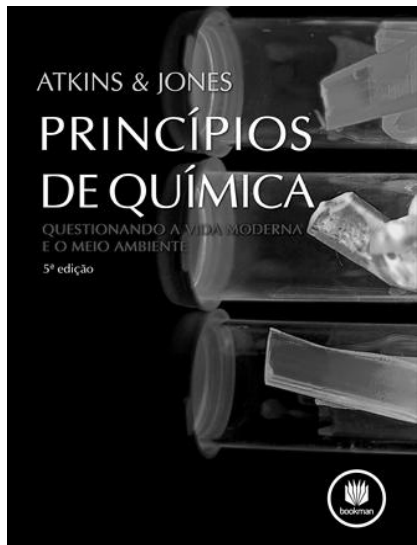

- ATKINS, P. W.; JONES, L. Princípios de química: questionando a vida moderna e o meio ambiente. Porto Alegre: Bookman, 2012.

O livro começa com uma "carta dos autores" dirigida aos docentes. Nas palavras dos autores, esta edição

foi concebida (...) a encorajar estudantes a pensar e a desenvolver uma compreensão sólida da química a partir de conceitos qualitativos (Atkins e Jones, 2012).

Isso mostra uma preocupação de que o livro não passe a falsa impressão de ser um manual, uma enciclopédia, mas uma fonte de enriquecimento de 
raciocínio e reflexão acerca da química. Ou seja, não seria apenas um livro para se formar um "técnico" químico, mas para se formar um "pensador" químico.

Por "compreensão sólida" pode-se também subentender um aprofundamento, por parte do educando, a respeito dos conteúdos presentes no livro, em especial, as implicações e consequências dos conhecimentos químicos. Ao indagar "O que temos que levar em conta?", os autores remetem ao raciocínio esperado pelos alunos quanto à resolução de exercícios, não como um problema unicamente matemático e químico, mas procurando englobar diversas ações envolvidas nesse processo de resolução. Os autores aparentemente pretendem, através desses problemas, exercitar a mente dos estudantes a pensar amplamente no problema apresentado, quais as possíveis formas de solucioná-lo e como chegar ao melhor resultado. Nesse ponto, se pode considerar que a melhor solução para um problema químico (problema, aqui, entendido como uma situação real, e não apenas uma questão didática exemplar) inclui considerações de natureza ética, conforme sugerido por Kovac (2000; 2004).

O livro de Atkins e Jones (2012) apresenta uma seção "Pontos para pensar" que, segundo as intenções declaradas pelos autores, objetiva "levar os alunos a pensarem enquanto aprendem", que é a ideia principal para uma aprendizagem significativa, e que também reforça a ideia da formação de "pensadores químicos".

O "capítulo 0" se chama "Fundamentos", e serve para introduzir a química a alunos com diferentes níveis de familiaridade com essa ciência. Isso sugere que o livro pode e deve ser usado por estudantes engajados em diferentes carreiras. Na Universidade de São Paulo, por exemplo, não somente os alunos do curso de Química usam este livro, mas também os de Farmácia, Geologia, Engenharia e 
Ciências da Natureza. Este "capítulo 0" apresenta algumas relações entre a química e suas implicações sociais. Os autores apresentam a química atual como uma construção demorada, constituída por constantes pesquisas e descobertas, e bastante voltada a um ideal de progresso; assim, a química seria parte fundamental do aperfeiçoamento da sociedade.

Sobre as atividades "químicas" do passado, os autores escrevem: "As pessoas não se davam conta de que estavam fazendo química ao transformar (...) pedras (...) em metais”. Dessa forma, os autores sugerem que a química seria uma categoria pré-existente e atemporal, mais do que uma construção humana. Pode-se dizer que as pessoas sempre transformaram a matéria, e continuam a transformá-la: dar a um conjunto dessas atividades o nome de química, e unificálas com princípios teóricos comuns é um processo histórico. Dito de outra forma, esse trecho sugere, conforme argumentou Ziman (1979), a confusão entre a ciência e seus produtos ou, ainda, entre a ciência e os fenômenos (naturais ou artificiais). De fato, até hoje, considerável parcela da população não se dá conta disso, devido à carência de aprofundamento do pensamento sobre a química, ou mesmo de compreensão significativa a respeito do que seja a ciência.

Mais adiante, os autores mencionam os avanços que o domínio de transformações químicas propiciou para a humanidade, como a criação de armas, moedas, vidros, etc. Uma Natureza perigosa foi transformada em uma Natureza dominável pelo ser humano, passando pelas mudanças na indústria, agricultura e tecnologia em geral. Nesse contexto, os autores destacam que o controle sobre a Natureza pode também trazer efeitos indesejáveis, e ressaltam, de maneira enfática, o papel que os químicos podem desempenhar em relação a isso: 
Talvez você colabore para o começo de uma nova fase da civilização (...). Talvez você possa ajudar a reduzir o impacto desastroso do progresso sobre o nosso meio ambiente (Atkins e Jones, 2012).

Esse trecho sugere que a mesma ciência que destrói o ambiente será capaz de salvá-lo. O risco, nesse caso, é reforçar a postura de que podemos continuar a degradar o ambiente pois, "no futuro", a ciência e a tecnologia serão capazes de reverter o processo.

Os autores falam sobre o método científico e que "os melhores cientistas são (...) cuidadosos e criativos". Observa-se, ainda que de passagem, a presença da ética no trabalho científico e a responsabilidade como um adjetivo positivo para cientistas. Mais adiante, os autores afirmam que "A química está verdadeiramente no centro da ciência". Esse tipo de afirmação, embora apresente os louváveis sentimentos dos autores quanto à química, podem induzir o aluno a uma visão de sobrevalorização da química. Seria necessário não perder de vista que a química é uma construção humana a respeito da Natureza e que, apesar de poder ser considerada central, no sentido de estabelecer relações com as demais ciências da Natureza, deve ser entendida como parte de um empreendimento mais amplo, que seria o conjunto das ciências, cada qual com sua importância.

No Capítulo 1, Atkins e Jones (2012) mencionam alguns aspectos históricos, apresentando superficial e idealizadamente o que seria o trabalho científico, e como os cientistas teriam chegado às ideias que são expostas aos alunos atuais. Por exemplo, os autores mencionam as ideias de Dalton e de Thomson sobre os átomos. São citados os experimentos de Thomson com os raios catódicos, que levaram à "descoberta" dos elétrons, presentes em todos os 
elementos. O capítulo apresenta de forma simplificada, e arranjados em uma sequência que é didática (mas não é histórica), os procedimentos, cálculos e a repercussão do trabalho de Thomson, e como teriam servido para que pesquisadores posteriores, com o advento de tecnologias mais avançadas, realizassem cálculos mais rápidos e medições mais precisas, levando ao aprimoramento do modelo atômico. É interessante observar que, nas poucas ocasiões em que os autores se referem aos cientistas, nunca são mencionadas as dificuldades envolvidas em seus trabalhos, nem o tempo necessário para a construção de suas conclusões. Dessa forma, reforça-se a impressão de que os cientistas trabalham fora de seu contexto social e até mesmo fora do tempo, sugerindo a imagem de pessoas que propõem ideias novas repentinamente, em lampejos de genialidade.

Em geral, são apresentados, como parte integrante do texto, alguns personagens mais conhecidos da história da química, ilustrados com fotos ou retratos desses químicos. Isso é positivo por emprestar uma dimensão humana ao empreendimento científico, ainda que não seja comum a presença de dados históricos mais aprofundados sobre os cientistas: geralmente, constam apenas o nome e as datas de nascimento e morte dos personagens citados (Fernandes e Porto, 2012). De fato, a história da química é imensa e complexa, e seria impossível aprofundar todos os episódios de interesse em um livro didático. Entretanto, o detalhamento de uns poucos casos poderia contribuir para a formação do estudante, no sentido de Ihe propiciar uma visão mais apropriada a respeito de como o conhecimento químico é construído (Fernandes e Porto, 2012). 
Em alguns capítulos, as seções de exercícios trazem questões que podem ser relacionadas ao ambiente e a problemas relativos à poluição.

Ocasionalmente, aparecem no texto relações com outras áreas do conhecimento, dentro de caixas de texto, isto é, à parte do texto principal. Um exemplo se refere à produção de fármacos a partir de produtos naturais, ou seja, a utilização de compostos encontrados na Natureza. $O$ recurso às caixas de textos, que aparecem também na abordagem de outros assuntos, pode ser positivo ou negativo: tanto pode dar um destaque visual ao texto nela contida, atraindo a atenção do leitor, quanto pode levar o estudante a considerar que ela encerra material "suplementar", não fundamental, que pode ser deixado de lado ao se estudar o capítulo.

Assuntos de grande relevância para a sociedade atual são mencionados nessa obra. O quadro 7.2 do livro de Atkins e Jones apresenta a questão dos combustíveis fósseis, discorrendo brevemente sobre a sustentabilidade e sobre a poluição gerada pelos combustíveis fósseis, e adentra o conteúdo relacionado à química, sugerindo, no texto, a consulta ao quadro 15.1 para saber mais sobre 0 efeito estufa. 


\section{QUADRO 7.2 O que isso tem a ver com... o meio ambiente?}

Combustiveis alternativos

Nosso complexo estilo de vida moderno só tornou-se possível pela descoberta e refinamento dos combustíveis fósseis, que são o resultado da decomposição da matéria orgânica enterrada há milhōes de anos. O gás natural que aquece nossas casas, a gasolina que abastece nossos automóveis e o carvão que fornece grande parte da energia elétrica são combustiveis fósseis. Vastas reservas de petróleo, a fonte de combustíveis hidrocarbonetos líquidos, tais como a gasolina, e de carvão existem em várias regiōes do mundo. Entretanto, embora imensas, essas reservas são limitadas e nós as estamos usando muito mais rapidamente do que novas reservas são descobertas.

Métodos alternativos e autossustentáveis de geração de energia, como as energias hidrelétrica, eólica e solar, e combustíveis alternativos estão sendo estudados para reduzir a demanda sobre os combustiveis fósseis. Quatro dos mais promissores combustíveis alternativos são o hidrogênio, o etanol, o metano e o biodiesel. O hidrogênio pode ser obtido da água dos oceanos por eletrólise. O etanol é obtido pela fermentação da biomassa, um nome dado a materiais vegetais que podem ser queimados ou que podem reagir para produzir combustíveis. O metano é gerado pela digestão bacteriana de resíduos, como detritos e resíduos agrícolas. Nesses casos, o combustível é renovável. Isso significa que a fonte de combustível é a cada ano reabastecida pelo Sol. O uso de hidrogênio como combustivel é discutido na Seção 15.3. Veremos, aqui, o etanol, o metano e o biodiesel.

$\mathrm{O}$ etanol, $\mathrm{CH}_{3} \mathrm{CH}_{2} \mathrm{OH}$, é produzido a partir da fermentação biológica do amido de grãos, principalmente o milho. Ele é usado como aditivo da gasolina ou como "E85", que é uma mistura contendo $85 \%$ de etanol e $15 \%$ de gasolina por volume. Atualmente, representa cerca de $10 \%$ do volume da gasolina usada nos Estados Unidos, o que reduz a poluição e o uso do petróleo. A Lei Federal de Energia dos Estados Unidos, de 2005 , exige que 7,5 bilhōes de galões $\left(2,8 \times 10^{10}\right.$ L) de combustível renovável sejam usados por ano. A Lei de
Independência e Segurança de Energia, de 2007, exige que até 2022 , o uso anual de combustiveis renováveis aumente para 36 bilhões de galões $\left(1,4 \times 10^{11} \mathrm{~L}\right.$, cerca de $23 \%$ do volume total anual de combustíveis líquidos usados nos Estados Unidos).

$\mathrm{O}$ átomo de oxigênio da molécula de etanol reduz as emissões de monóxido de carbono e hidrocarbonetos, ajudando a assegurar a combustão completa. Entretanto, como o etanol já é parcialmente oxigenado, ele fornece menos energia por litro. A milhagem atual de um automóvel que usa E85 é $15 \%$ inferior à de um que usa gasolina pura. Um "bushel" de milho (cerca de $30 \mathrm{~L}$ ) pode produzir aproximadamente $10 \mathrm{~L}$ de etanol. Um problema do etanol como combustivel é que os açúcares e os amidos fermentados para produzi-los são geralmente caros. Entretanto, a celulose de palha e talos de milho descartados como refugo, após a colheita dos grãos, estão agora atraindo a atenção. A celulose é o material estrutural das plantas (veja a Seção 19.14). Ela

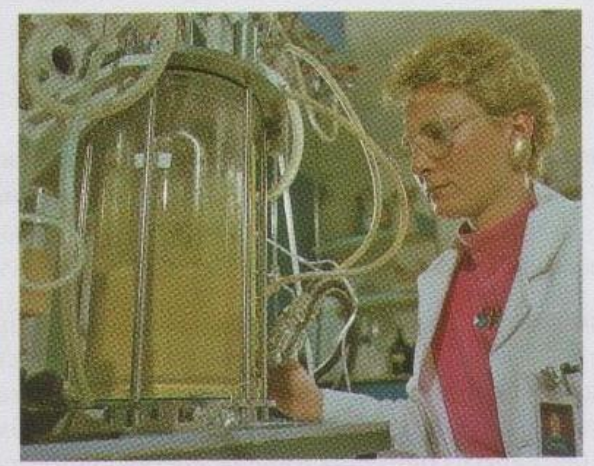

A biomassa, composta de resíduos de celulose, deste reator está sendo digerida por enzimas especiais que a decompõem em etanol. Essas enzimas estão sendo muito estudadas para aumentar a eficiência da conversão.

Figura 1: Primeira parte do quadro 7.2 


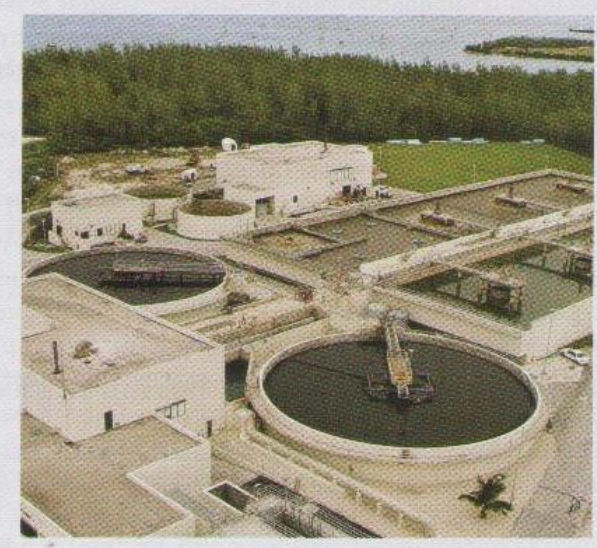

Estes tanques em uma estação de tratamento de água são usados para gerar uma mistura de metano e dióxido de carbono pela digestão anaeróbica de esgoto. O metano produzido fornece uma boa parte da energia necessária para manter a estação em funcionamento.

é formada por açúcares mais simples, como também acontece com o amido, mas a bactéria que fermenta o amido não pode digerir a celulose. Pesquisas estão sendo realizadas com enzimas capazes de quebrar as moléculas de celulose em açúcares que podem ser digeridos. Este processo aumentaria muito a quantidade de biomassa disponível para a produção de combustíveis, porque a palha, a madeira, a grama e praticamente todos os materiais vegetais poderiam ser usados para produzir combustíveis. Também resolveria parcialmente o problema da produção de combustivel competir com a produção de alimentos.

$\mathrm{O}$ metano, $\mathrm{CH}_{4}$, é encontrado em reservas, sob o solo, como o componente principal do gás natural. Ele também é obtido a partir de materiais biológicos, mas a "digestão" dos biomateriais é anaeróbica, ou seja, ela ocorre na ausência de oxigênio. Atualmente, muitas plantas de tratamentos de esgotos têm digestores anaeróbicos que produzem o metano utilizado para operar as plantas. Para gerar metano por digestão anaeróbica em larga escala, outros materiais, como açúcares obtidos pela quebra enzimática da biomassa, teriam de ser usados. O metano seria menos útil do que o etanol como combustível para transporte por causa de sua baixa densidade entálpica, isto é, a entalpia de combustão por litro. Entretanto, ele pode ser usado em todo lugar em que o gás natural é usado.

Biodiesel é o termo usado para descrever o combustivel obtido de fontes renováveis, biológicas, como óleos vegetais. Mesmo óleos usados, como os descartados de restaurantes, podem ser filtrados e usados como biodiesel. Os motores a diesel são mais eficientes do que os motores a gasolina, porque o combustível tem densidade de energia (entalpia de combustão por litro) maior. O problema com o biodiesel é que ele é mais viscoso do que a gasolina e pode solidificar em temperaturas baixas.

Estes combustiveis alternativos produzem dióxido de carbono quando queimados e, portanto, contribuem para o efeito estufa e o aquecimento global (Quadro 15.1). Entretanto, eles podem ser renovados a cada ano, contanto que o Sol continue a brilhar e produza plantas verdes.

Exercícios relacionados: 7.45-7.47, 7.52, 7.54, 7.103, 7.115.

Leitura complementar: Alternative Fuels \& Advanced Vehicles Data Center, http://www.afdc.energy.gov/afdd/ (U.S. Department of Energy, 2009). A Student's Guide to Alternative Fuel Vehicles, http://www. energyquest.ca.gov/transportation/ /California Energy Commission, 2005). M. Allen, "Crunching the Numbers on Alternative Fuels," Popular Mechanics, May, 2006, http://www.popularmechanics.com/ science/earth/2690341.html.

Figura 2: Segunda parte do quadro 7.2 


\section{QUADRO 15.1 Q que isso tem a ver com .... o meio ambiente?}

\section{O efeito estufa}

A cada ano, nosso planeta recebe do Sol energia radiante mais do que suficiente para cobrir todas as nossas necessidades. Cerca de $55 \%$ da radiação solar é refletida ou é usada em processos naturais. Os restantes $45 \%$ são convertidos em movimentos térmicos (calor), a maior parte dos quais escapa como radiação infravermelha entre 4 e $50 \mu \mathrm{m}$.

$\mathrm{O}$ efeito estufa é a retenção dessa radiação infravermelha por certos gases da atmosfera. $\mathrm{O}$ resultado é o aquecimento da Terra, como se o planeta inteiro estivesse cercado por uma enorme estufa ${ }^{\circ}$. O oxigênio e o nitrogênio que, juntos, formam aproximadamente $99 \%$ da atmosfera, não absorvem radiação infravermelha, porém o vapor de água e o $\mathrm{CO}_{2} \mathrm{ab}$ sorvem. Ainda que esses gases representem apenas cerca de $1 \%$ da atmosfera, eles retêm radiação suficiente para aumentar em cerca de $33^{\circ} \mathrm{C}$ a temperatura da Terra. Sem esse efeito estufa natural, a temperatura média da superfície da Terra seria bem inferior ao ponto de congelamento da água.

Os gases de estufa mais importantes são o vapor de água, o dióxido de carbono, o metano, o óxido de dinitrogênio (óxido nitroso), o ozônio e certos cloro-fluorocarbonetos. A água é o mais importante deles. Ela absorve fortemente próximo de $6,3 \mu \mathrm{m}$ e em comprimentos de onda superiores a $12 \mu \mathrm{m}$, como se pode ver na ilustração. O dióxido de carbono da atmosfera absorve cerca da metade da radiação infravermelha de comprimento de onda 14-16 $\mu \mathrm{m}$ (veja o gráfico, à direita).

Acredita-se que a concentração do vapor de água na atmosfera permanece constante, mas que a concentração de alguns outros gases de estufa está subindo. Do ano 1000 ou de antes disso, até cerca de 1750 , a concentração de $\mathrm{CO}_{2}$ na atmosfera permaneceu razoavelmente constante em cerca de $280 \pm 10$ partes por milhão por volume (ppmv). Desde então, a concentração de $\mathrm{CO}_{2}$ aumentou, alcançando 379 ppmv (veja o segundo gráfico). A concentração de metano, $\mathrm{CH}_{4}$, mais do que dobrou durante este tempo e está agora em seu nível mais elevado em 160.000 anos. Estudos de bolsas de ar presas no gelo da Antártica mostraram que mudanças da concentração do dióxido de carbono e do metano da atmosfera, nos últimos 160.000 anos, se correlacionam bem com mudanças da temperatura da superfície do globo. $\mathrm{O}$ aumento

* O mecanismo de aquecimento de uma estufa é diferente. $O$ vidro não só inibe a perda da radiação infravermelha como mantém o ar quente no interior da estufa.

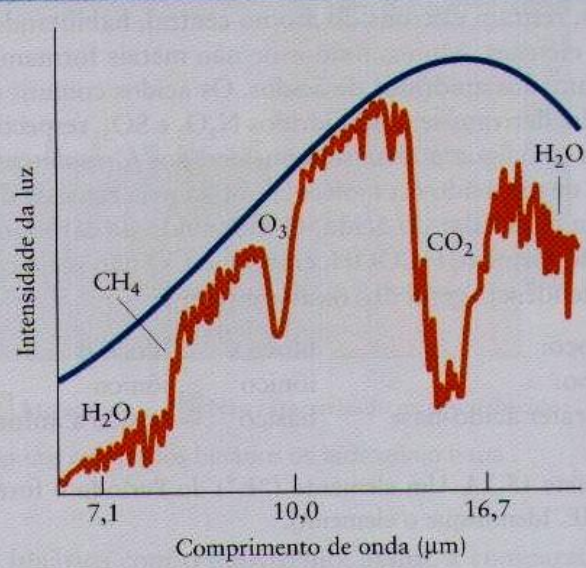

A linha contínua mostra a intensidade da radiação infravermetha em vários comprimentos de onda que seriam perdidas pela Terra na ausência do efeito estufa. A linha descontínua mostra a intensidade da radiação emitida. O comprimento de onda máximo da radiação absorvida por cada gás de estufa está indicado.

das concentrações de dióxido de carbono e metano é, portanto, causa de preocupação.

De onde vem o $\mathrm{CO}_{2}$ adicional? As atividades humanas são as responsáveis. Uma parte é gerada pelo aquecimento e decomposição de $\mathrm{CaCO}_{3}$ na fabricação do cimento (veja a Seção 6.8). Grandes quantidades de $\mathrm{CO}_{2}$ são também liberadas para a atmosfera devido ao desmatamento, que envolve a queima de grandes áreas de vegetação. Entretanto, a maior parte vem da queima de combustíveis fósseis, que começou a ser praticada em grande escala após 1850 e aumentou cerca de $80 \%$ entre 1970 e 2004 . O metano adicional vem principalmente da indústria de petróleo e da agricultura.

A temperatura da superfície da Terra está aumentando cerca de $0,2^{\circ} \mathrm{C}$ por década (veja o gráfico). Se as presentes tendências de crescimento da população e do uso de energia continuarem, lá pela metade do século XXI a concentração de $\mathrm{CO}_{2}$ na atmosfera atingirá o dobro do valor anterior à Revolução Industrial. Quais seriam as prováveis consequências da duplicação da concentração de $\mathrm{CO}_{2}$ ?

O Painel Intergovernamental da Mudança do Clima (IPCC) estimou, em 2001, que em torno de 2100 a Terra so-

Figura 3: Primeira parte do quadro 15.1 


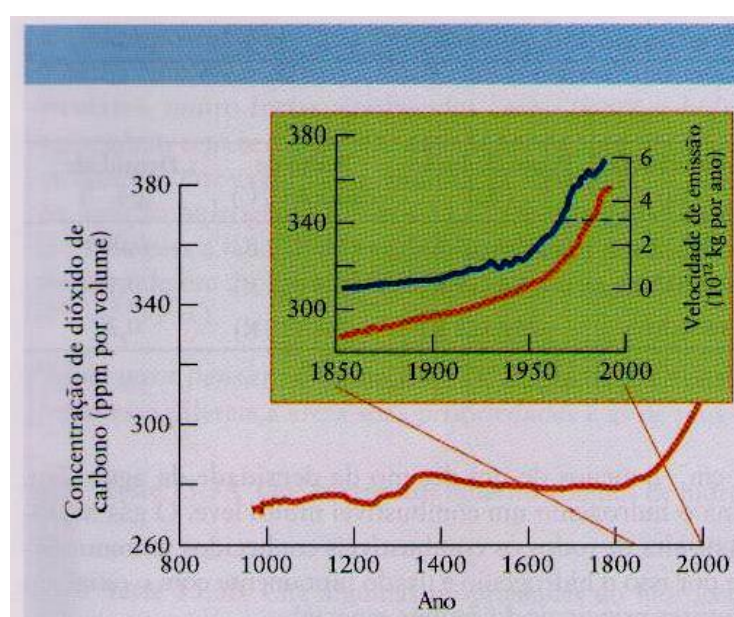

Concentração de dióxido de carbono na atmosfera nos últimos 1000 anos, determinado por medidas em gases retidos no gelo. A linha azul mostra a emissão de $\mathrm{CO}_{2}$.

frerá um aquecimento de $3^{\circ} \mathrm{C}$, com um aumento de cerca de $0,5 \mathrm{~m}$ no nível do mar. Um aumento de $3^{\circ} \mathrm{C}$ parece pequeno, porém a temperatura durante a última idade do gelo foi de apenas $6^{\circ} \mathrm{C}$ inferior ao que é hoje. Além disso, a velocidade do aquecimento será provavelmente mais alta do que em qualquer momento dos últimos 10.000 anos. Mudanças rápidas do clima podem ter efeitos destrutivos em muitos ecossistemas da Terra.

Projeçōes computadorizadas da concentração de $\mathrm{CO}_{2}$ atmosférico para os próximos 200 anos predizem um forte aumento de concentração. Somente metade do $\mathrm{CO}_{2}$ liberado pelos humanos é absorvido pelos sistemas naturais da Terra. A outra metade aumenta a concentração de $\mathrm{CO}_{2}$ atmosférico cerca de 1,5 ppmv por ano. Duas conclusões podem ser tiradas desses fatos. Primeiramente, mesmo se as emissões de $\mathrm{CO}_{2}$ fossem reduzidas aos níveis de 1990 e mantidas constantes, a concentração de $\mathrm{CO}_{2}$ na atmosfera cotinuaria a crescer cerca de 1,5 ppmv por ano no próximo século. Em segundo lugar, para manter o $\mathrm{CO}_{2}$ na concentração atual de 360 ppmv, teríamos de reduzir o consumo de combustivel fóssil a $50 \%$ imediatamente.

Alternativas aos combustíveis fósseis, como o hidrogênio, são exploradas no Quadro 7.2 e na Seção 15.3 . O carvão, que é essencialmente carbono, pode ser convertido em combustíveis com uma proporção menor de carbono. Sua

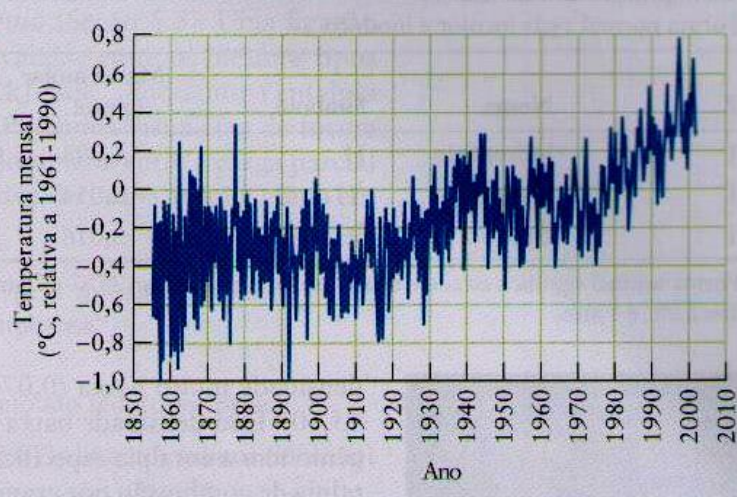

Mudança média da temperatura da superfície da Terra entre 1985 e 2002, em comparação com a temperatura média durante 1961-1990.

conversão em metano, por exemplo, reduziria as emissões de $\mathrm{CO}_{2}$ por unidade de energia. Também poderíamos colaborar com a natureza, acelerando a absorção de carbono pelos processos naturais do ciclo do carbono. Uma solução proposta é bombear $\mathrm{O} \mathrm{CO}_{2}$ produzido para o fundo do oceano, onde ele se dissolveria para formar ácido carbônico e íons bicarbonato. $O$ dióxido de carbono também pode ser removido dos gases de exaustão das usinas de força passando-os por uma suspensão de silicato de cálcio em água para produzir produtos sólidos inofensivos:

$$
2 \mathrm{CO}_{2}(\mathrm{~g})+\mathrm{H}_{2} \mathrm{O}(\mathrm{l})+\mathrm{CaSiO}_{3}(\mathrm{~s}) \longrightarrow \mathrm{SiO}_{2}(\mathrm{~s})+\mathrm{Ca}\left(\mathrm{HCO}_{3}\right)_{2}(\mathrm{~s})
$$

\section{Exercícios relacionados: $15.107-15.109$}

Leitura complementar: P. Cox \& C. Jones, "Climate Change: Illuminating the modern dance of climate and $\mathrm{CO}_{2}$," Science, vol. 321, 2008, pp. 1642-1644. Intergovernmental Panel on Climate Change, Climate Change 2007 Synthesis Report, IPCC, 2008. R. A. Kerr, "A worrying trend of less ice, higher seas," Science, vol. 311, 2006, pp. 1698-1701. F. W. Zwiers and A. J. Weaver, "The causes of 20th century warming," Science, vol. 290, 2000, pp. 2081-2083. The US Environmental Protection Agency, "Climate Change," http://www.epa. gov/climatechange/.

Figura 4: Segunda parte do quadro 15.1

\section{A interdisciplinaridade é também utilizada como ferramenta para}

sensibilizar o aluno sobre o conteúdo a ser abordado, relacionando-o com conhecimentos de outras grandes áreas, como a biologia. Outro exemplo de conteúdo relevante, que é abordado também em uma caixa de texto, é a chuva ácida. Os autores destacam como a chuva ácida afeta negativamente a 
biodiversidade, e apresentam fórmulas químicas que consideram integrar a discussão dos dois assuntos.

\section{Livro 2: Brown, LeMay e Bursten}

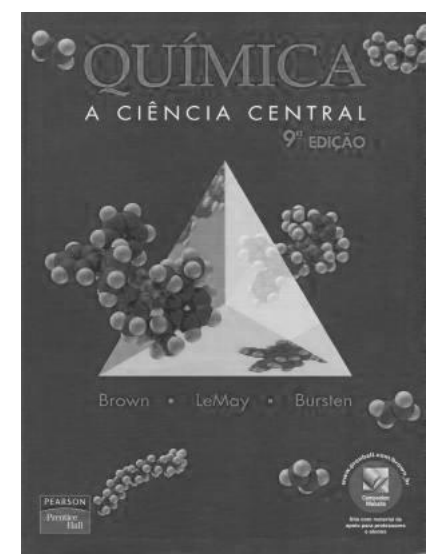

- BROWN, T. L.; LeMAY, H.; BURSTEN, B. E. Química: a ciência central. São Paulo: Pearson Prentice Hall, 2005.

O prefácio para os professores apresenta, logo de início, a filosofia do livro, que pretende abordar a química de forma a associar os conteúdos com o cotidiano do aluno, em uma visão mais utilitarista que, segundo os autores, favorece a curiosidade e entusiasmo do aluno em aprender. A visão utilitarista adotada não chega a aprofundar as questões relativas ao papel da química na sociedade. Naturalmente, é indispensável a figura ativa do professor para guiar o aluno a reflexões mais aprofundadas, o que demanda tempo. Além disso, os autores enfatizam as mudanças que a química sofre constantemente, procurando fazer atualizações e adaptações ao conteúdo do livro. Também sugerem uma forma de estudo, apresentando tópicos e sugestões, como a valorização do 
professor e das aulas, a tomada de notas, e a leitura prévia dos tópicos a serem abordados.

O livro apresenta brevemente, no primeiro capítulo, alguns assuntos relacionados à formação profissional e acadêmica do aluno, como os cargos existentes em uma indústria química, mostrando novamente a importância social da química, e o que busca o mercado de trabalho. Assim como em outros livros, os autores apresentam esses assuntos dentro de caixas de texto, cuja leitura pode ser negligenciada sem comprometer o entendimento do texto principal.

$\mathrm{Na}$ parte destinada ao estudo da estrutura da matéria, é oferecida uma pequena introdução histórica, com fatos não muito relevantes e dispersos, abordando os cientistas de maneira superficial, e apresentando alguns dados como onde o cientista morou, ou quando morreu. A parte que mais apresentou dados sobre a vida dos cientistas foi a discussão sobre modelos atômicos. Em certa passagem, os autores julgaram relevante destacar, a respeito do físico Werner Heisenberg (1901 - 1976), que ele foi "um dos mais jovens cientistas a receber o Prêmio Nobel" (quando ele contava apenas 31 anos). A intenção dos autores é, provavelmente, instigar o aluno jovem a se empenhar, servindo como inspiração para seguirem as carreiras científicas. Entretanto, o leitor pode ficar com a impressão de que a ciência é feita por gênios, assimilando uma visão distorcida e não se identificando com a profissão.

Um quadro que chamou a atenção foi aquele intitulado "A química no trabalho" (p. 88), no qual os autores discorrem sobre o efeito estufa, um assunto que volta a ser abordado no capítulo 18. Também é mencionado, em seção que trata de energia, o desenvolvimento de carros híbridos (elétricos e a combustíveis) como alternativa para os problemas causados pelos automóveis 
movidos a combustíveis fósseis. Entretanto, os autores não chegam a problematizar os interesses envolvidos na fabricação de automóveis, e na eventual redução da participação das empresas petrolíferas na matriz energética mundial. Ou seja, o livro se prende às questões mais técnicas da química em relação aos problemas da sociedade, mas os autores não se preocupam em estabelecer relações com questões mais amplas, que envolvam outros âmbitos que não apenas os estritamente técnicos.

Em alguns momentos, o livro apresenta curiosidades, com implicações em vários âmbitos, inclusive o social, sem maiores aprofundamentos. São exemplos de temas que poderiam ser mais desenvolvidos: as consequências de determinadas pesquisas com fármacos; ou os componentes de bebidas e alimentos que podem ser prejudiciais à saúde humana.

Uma questão sobre poluição foi abordada em um quadro na p. 499, no qual se discute o uso do brometo de metila, que catalisa a decomposição de ozônio na atmosfera terrestre. O brometo de metila é utilizado, segundo o livro, para produção de antifúngicos em sementes de plantas, mas apresenta esse efeito colateral indesejável. Novamente, mostra-se necessária a figura do professor para encaminhar e aprofundar a discussão.

No capítulo sobre equilíbrio químico, foi discutido em detalhes o sistema envolvendo os gases $\mathrm{NO}_{2}$ e $\mathrm{N}_{2} \mathrm{O}_{4}$. Ao final do capítulo, abordou-se a questão ambiental abrangendo esse particular equilíbrio químico; no entanto, apesar de ser um assunto importante e atual, relacionado à poluição em regiões metropolitanas, com importantes consequências para a saúde pública, foi mencionado apenas no final do capítulo, dentro de uma caixa de texto. 
Em seu capítulo 21, o livro aborda a química nuclear, e cita as bombas de Hiroshima e Nagasaki no corpo do texto principal, acrescentando mais informações sobre o chamado "Projeto Manhattan" em uma caixa de texto. É interessante notar que este é o único, dentre os livros de química geral analisados, a mencionar o acidente com material radioativo ocorrido em 1987 em Goiânia, no qual dezenas de pessoas foram expostas à radiação emitida por uma amostra de césio-137 irresponsavelmente manipulada por pessoas que desconheciam o material com que estavam lidando. Esse desconhecimento custou a vida de quatro pessoas em poucas semanas após a contaminação, e acredita-se que mais de 100 pessoas foram vitimadas por consequências de longo prazo da exposição à radiação. Trata-se de um exemplo dramático de como a ignorância sobre questões básicas de ciência pode gerar eventos trágicos.

\section{Livro 3: Chang}

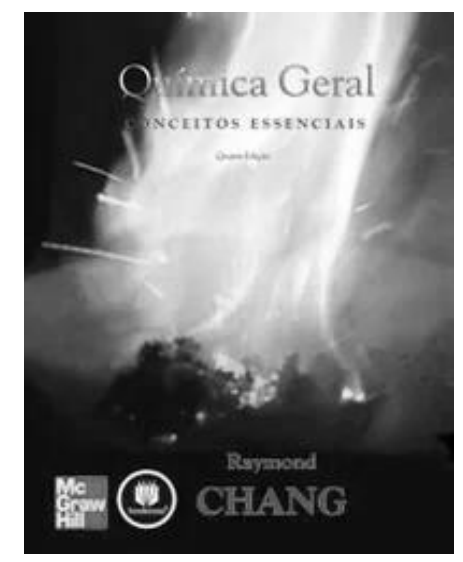

- CHANG, R. Química Geral - Conceitos essenciais. São Paulo: McGraw-Hill, 2007. 
Um ponto digno de nota no livro de Chang é o fato de o autor valorizar a figura do professor em sala de aula, como um facilitador da aprendizagem. $\mathrm{O}$ autor é enfático no que diz respeito ao pensamento crítico, sugerindo ao alunoleitor que pense sempre de maneira crítica, se questionando se compreendeu plenamente algum conceito. Evidentemente, essa postura pode e deve ser aplicada a todos os conteúdos, não somente aos cálculos de equações e palavras novas nos vocabulários, mas também no que tange às relações entre a química e a sociedade.

O autor convida o leitor a entender o meio da pesquisa científica, atribuindo o "amor" como um componente do trabalho de pesquisa dos cientistas - o que não deixa de ser uma observação pouco usual em textos da área de ciências da Natureza. Além disso, se valendo de sua origem chinesa, o autor apresenta, logo no começo do capítulo introdutório, os caracteres chineses que, traduzidos ao pé da letra, significam "estudo das transformações", e que, segundo ele, fornecem o melhor significado para a palavra "química".

De fato, cada conceito é explicado em profundidade, havendo ao final de cada capítulo um resumo, como um índice analítico com a página onde cada palavra-chave foi mencionada, além de exercícios com diferentes níveis de dificuldade e as respostas aos exercícios numéricos, sem a sua respectiva resolução completa. Ao longo do texto principal dos capítulos, porém, aparecem as resoluções completas de alguns exercícios exemplares. Os pontos principais do texto são colocados em destaque nas laterais da página, assim como as indicações de recursos online, de referências externas, ou de tópicos a serem retomados mais adiante no próprio livro. 
O livro, porém, carece da apresentação de fatos históricos aprofundados, trajetórias dos cientistas e questões éticas e ambientais. Esses aspectos, nas raras vezes em que são mencionados, aparecem como períodos simples, nas legendas de fotos pequenas na lateral da página, por exemplo, não sendo citados no texto principal.

Esse livro, considerando-se apenas o quesito conteúdo cognitivo para a formação de químicos para a indústria, é excelente; entretanto, o autor não parece ter se preocupado com a formação de um profissional completo, em especial quanto a reflexões sobre o papel da química na sociedade. Os conteúdos conceituais e procedimentais são riquíssimos, com muitos detalhes e aprofundamentos, com muitos dados numéricos e exercícios bem explicados. Aparentemente, o autor se concentrou em outro grave problema da educação atual: o ensino de matemática, talvez negligenciando outros aspectos de uma formação cidadã. Assim, como manual de química, o livro é esplêndido; mas, como auxiliar na formação de profissionais pensantes, deixa muito a desejar.

\section{Livro 4: Garritz e Chamizo}

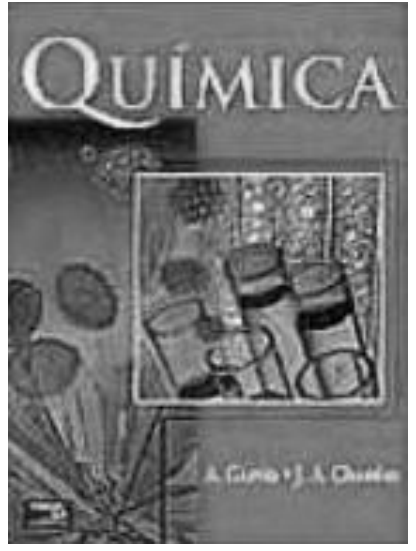


- GARRITZ, A.; CHAMIZO, J. A. Química. Delaware: Addison-Wesley Iberoamericana, 1994.

O livro, impresso em preto e branco, começa com questões-chaves do cotidiano, aparentemente simples, mas difíceis de responder, de maneira a instigar a curiosidade do aluno em relação à química.

Os autores expressam com clareza alguns dos problemas relativos ao ensino de química. Nesse sentido, consideraram três dimensões ao elaborar o livro, a saber: (i) dimensão cognitiva; (ii) dimensão psicológica; (iii) dimensão sócio-filosófica. Estes aspectos são considerados, pelos autores, como determinantes de um ensino de qualidade e de uma aprendizagem significativa, para a formação de químicos pensantes e atuantes socialmente.

O primeiro capítulo relaciona a química com o cotidiano, considerando a química como uma criação humana para exercer o domínio sobre a Natureza. Os autores mostram a presença da química em múltiplas instâncias ao nosso redor, como em remédios, computadores, arqueologia e artes. Os autores discutem conceitos a partir da primeira pergunta: "O que é Ciência?", debatem a definição de Einstein ("A ciência é o intento de relacionar a diversidade caótica de nossa experiência sensorial com um sistema lógico e uniforme de pensamento", p. 10) e, por fim, explicam o "método científico" e a criação de modelos. Segue-se uma seção intitulada "A atitude científica como norma de comportamento". Nela, os autores argumentam que a ciência não se faz apenas em laboratórios, por pessoas especializadas que misturam os conteúdos de tubos de ensaio, mas deve ser feita em todos os momentos de nossas vidas, utilizando a capacidade racional e uma cuidadosa observação, supondo respostas e testando-as. Assim, 
os autores concluem que o estudo científico é mais uma viagem do que um destino. As questões propostas ao final dessa seção apresentam temas do cotidiano do aluno, sugerindo investigações na própria residência, consultas a outros livros, e discussões da relação do ser humano com o avanço tecnológico. Também se sugere um estudo aprofundado sobre dez cientistas, à escolha do aluno, e suas contribuições para a ciência. Ao final dessa seção, encontram-se sugestões de livros para os alunos buscarem mais conteúdos sobre os temas abordados, como raciocínio, ciência e tecnologia, e história da ciência.

Os autores se utilizam de reportagens publicadas em órgãos de imprensa para relacionar o cotidiano com a química, propondo reflexões aos alunos sobre os assuntos enfocados, além de usar da interdisciplinaridade para abordar a química sob outros aspectos, como biologia e a arte da civilização asteca précolombiana. O livro também apresenta cientistas latino-americanos que se destacaram na área de química, valorizando a presença latino-americana na produção da ciência. Dessa forma, os estudantes poderão se sentir mais próximos dos personagens que fazem a ciência, o que pode gerar mais interesse pela carreira científica (Fernandes e Porto, 2012). São apresentados também químicos de outras nacionalidades, como Dalton, o casal Curie, Van der Waals, entre muitos outros.

Ao final de algumas seções, aparecem "atividades complementares", nas quais se sugere, além de consultas a outros livros, consultas a periódicos científicos, além de exercícios para relacionar o tema com outras áreas do conhecimento.

O livro aborda poucas questões ambientais como temas para discutir conteúdos no texto, mas se pode destacar a discussão a respeito do fenômeno da 
inversão térmica. Por outro lado, os autores apresentam muitos aspectos biológicos, em especial relativos ao corpo humano.

Comparado a outros livros, pode-se dizer que obras como a de Chang, por exemplo, são mais completas em termos de conteúdos. No quesito de formação pessoal, o livro de Garritz e Chamizo é mais completo e aprofundado, pois explora melhor a construção do conhecimento por meio da história da ciência, estabelece mais relações com o cotidiano e o contexto social, e estimula o leitor a buscar mais conhecimentos em outras fontes.

\section{Livro 5: Kotz e Treichel}

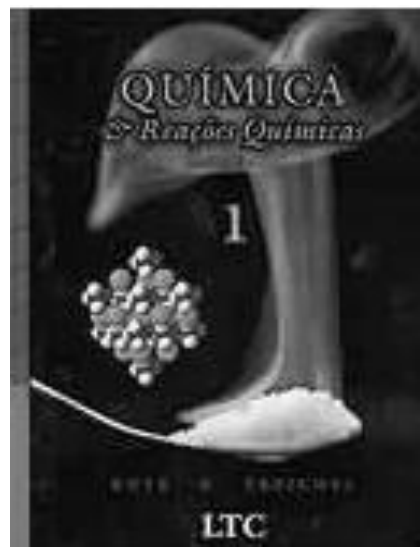

- KOTZ, J.C.; TREICHEL, P. Jr. Química e reações químicas. Rio de Janeiro: LTC, 2002.

O prefácio do livro explicita seu objetivo: "oferecer uma ampla visão dos princípios da química e da reatividade dos elementos e compostos químicos", além de associar a química a um mundo tecnológico. Aparentemente, houve uma tentativa de aproximar o mundo atual ao mundo da química, de maneira a situar o 
estudante de agora, das informações e da rapidez, dentro do universo das ciências.

Não diferentemente dos demais livros, os autores apresentam uma ordem "natural" de abordagem dos conteúdos, que se pretende adequada a um curso universitário. Entretanto, os autores inicialmente procuram associar outros assuntos ao livro, tais como a química no corpo humano, e problemas reais e recorrentes, como poluição e camada de ozônio.

O livro é impresso em preto e branco, mas possui um encarte em cores, com figuras selecionadas dos vários capítulos. Alguns textos, como aquele contido em uma caixa tratando sobre a destruição da camada de ozônio estratosférica, podem eventualmente passar despercebidos, devido ao pouco destaque proporcionado pelos elementos gráficos em preto e branco. De maneira geral, o livro se concentra nos conteúdos cognitivos da química, mas oferece poucas oportunidades de reflexão a respeito do papel da química na sociedade. Assim, embora bastante atualizado em termos da temática tecnológica, e de procurar dialogar com os estudantes do século XXI, o livro não estimula a formação de "pensadores" químicos, no sentido que delineamos acima. 


\section{Considerações Finais}

Analisando o livro de Atkins e Jones (2012), percebemos um esforço por parte dos autores para fazer com que o aluno reflita amplamente sobre os temas abordados. Para uma pesquisa futura, seria interessante investigar o quanto esses questionamentos atingiram os alunos, não como apenas mais um "dever de casa" a ser cumprido burocraticamente, mas buscando indagar o educando, provocando-o e questionando os próprios pensamentos, como uma autocrítica acerca das múltiplas dimensões de sua compreensão a respeito do assunto.

Um aspecto que foi possível observar nos livros didáticos analisados é que nenhum autor assume uma postura crítica em relação à química ou seus colegas, no sentido de colocar em discussão os rumos de seu desenvolvimento, corroborando as ideias de Laszlo (2006) da união entre químicos e de sua autoimagem de "benfeitores da humanidade". A abordagem histórica nos livros, em geral, é feita de maneira superficial, limitando-se à menção de nomes e datas. Muitas vezes, também, é feita de forma idealizada, pela seleção de alguns personagens e seus trabalhos, que são colocados em uma sequência didática, a 
qual não reflete a sequência histórica de fato ocorrida. A abordagem dos modelos atômicos é o mais frequente exemplo desse processo. No que tange à abordagem histórica, o livro de Garritz e Chamizo (1994) se diferencia dos demais, pois nele os autores fornecem alguns relatos um pouco mais detalhados a respeito de episódios históricos, propiciando oportunidades para a construção de uma imagem mais elaborada da ciência, e também para reflexões acerca das relações entre a química e a sociedade em diferentes ocasiões.

As questões ambientais oferecem boas possibilidades para se discutir, em contextos didáticos, o papel da química na sociedade; no entanto, nem sempre os livros didáticos analisados tiraram proveito disso. Atkins e Jones (2012) exploram, em alguma medida, essa temática, enquanto Brown, LeMay e Bursten (2005) e Kotz e Treichel (2002) se prendem mais a aspectos técnicos das questões ambientais, e Chang (2007) dá pouca atenção ao tema. Garritz e Chamizo (1994) também pouco abordam as questões ambientais, mas exploram as relações química-sociedade mais do que os outros autores, por meio de outras temáticas.

As ciências da Natureza são entendidas por alguns como áreas de estudo "confortáveis". Em uma abordagem simplista, os iniciantes nas áreas de ciências da Natureza podem acreditar que os resultados das investigações são binários, isto é, uma resposta a uma indagação acerca de um fenômeno ou está certa ou está errada; ou, visto de outra forma, uma observação pode ter seu resultado conhecido ou desconhecido. Uma formação científica mais diversa, mais ampla, pode abordar aspectos mais complexos e, especialmente, promover reflexões metacientíficas - de maneira a propiciar aos estudantes compreensões mais completas a respeito do fazer ciência, dos conteúdos da ciência, e de suas relações com a sociedade. Em particular, entre as reflexões metacientíficas, a 
ética proporciona o tempero entre os aspectos mais técnicos e especializados das áreas científicas e as decisões que devem caber aos profissionais de ciências em geral, e aos químicos em particular.

Na sociedade contemporânea, as ciências da Natureza ocupam lugar de destaque, e são valorizadas tanto na educação básica como no mercado de trabalho. De maneira contraditória, observa-se, em avaliações internacionais de conhecimentos escolares (como, por exemplo, o Programme for International Student Assessment, PISA), como as disciplinas de ciências oferecem dificuldades aos estudantes, estando entre as que geram notas mais baixas. Ainda que o ensino possa estar mais voltado ao mercado de trabalho do que à formação geral do indivíduo (ao contrário do que preveem as diretrizes curriculares mais modernas), não deixa de ser perturbador observar que sequer aquele objetivo seja atendido a contento.

Além disso, por maior que seja a importância do emprego e a subsistência, uma formação mais completa e diversificada poderia colocar melhores profissionais no mercado: pessoas críticas, éticas, para além do domínio de suas áreas de atuação. É preciso deixar claro, nos contextos didáticos, que a indústria química não é neutra, pois qualquer produção envolve interesses econômicos. Mesmo que se considere que o interesse econômico e o mercado são importantes para a manutenção da sociedade capitalista, sua economia, empregos, etc., é preciso explicitar esses aspectos, e não adotá-los como pressupostos naturais, pois isso contrariaria o ideal de formação de cidadãos críticos.

Tampouco a pesquisa pode ser apresentada como neutra, pois é fundamental reconhecer que limites éticos devem ser adotados. Mesmo as 
pesquisas científicas que não envolvem tecnologias ou aplicações mais imediatas, mas que se aproximam do ideal de ciência "pura" e desinteressada, necessitam igualmente de ética e neutralidade, pois podem ter consequências inicialmente insuspeitadas, em maior ou menor grau. Muitos problemas originados pela ciência e pela tecnologia poderiam ter sido evitados se houvesse profissionais mais reflexivos e responsáveis. Mais do que a questão da culpa individual, a problemática que envolve o ensino de ciências requer a reformulação no entendimento sobre a formação dos indivíduos para a prática das atividades científicas, seja por meio de inserção de disciplinas, seja pela interação com outras áreas do conhecimento, aulas interdisciplinares ou livros didáticos que estimulem essa finalidade reflexiva. Em geral, a frieza técnica contida nos livros didáticos não favorece a concretização dessa concepção de ensino; assim, o papel do professor se torna essencial para a transformação desejada.

A necessidade de mudanças nos currículos de formação de químicos, e dos professores de química em particular, seria uma forma de enfrentar algumas das muitas dificuldades com que se deparam os docentes dessa área. A falta de estímulo aos alunos e a falta de apoio ao profissional da educação têm gerado um sentimento de não importância por parte dos docentes, de difícil alcance em relação à química como ciência e disciplina escolar por parte dos estudantes.

Retomando a questão do Bildung, no sentido descrito por Sjöström (2007), uma formação de futuros pesquisadores que incluísse mais oportunidades de reflexões críticas sobre temas abrangentes resultaria em ambientes de pesquisa mais transparentes, reflexivos e responsáveis. Esses ambientes de pesquisa, abarcando um espectro maior de conhecimentos e ideologias, seriam propícios ao 
desenvolvimento de investigações mais criativas, inovadoras, diversas e responsáveis. 


\section{Referências Bibliográficas}

ATKINS, Peter W.; JONES, Loretta. Princípios de química: questionando a vida moderna e o meio ambiente. Porto Alegre: Bookman, 2012.

BAIRD, D.; SCERRI, E.; McINTYRE, L. (eds.) Philosophy of Chemistry synthesis of a new discipline. Dordrecht: Springer, 2006.

BRASIL. Decreto-Lei no 1006 de 30 de dezembro de 1938.

BRASIL. Ministério da Educação. Secretaria da Educação Média e Tecnológica.

Parâmetros Curriculares Nacionais. Ciências Naturais. Brasília: MEC/SEF, 1998. Disponível em: http://portal.mec.gov.br/seb/arquivos/pdf/ciencias.pdf. Acesso em 07 de jan. 2012.

BRASIL. Ministério da Educação. Secretaria da Educação Média e Tecnológica.

Parâmetros Curriculares Nacionais. Temas Transversais: Ética. Brasília: MEC/SEF, 1998.

Disponível

em:

http://portal.mec.gov.br/seb/arquivos/pdf/ttransversais.pdf. Acesso em 07 de jan. 2012. 
BRASIL. Ministério da Educação. Secretaria da Educação Média e Tecnológica. Parâmetros Curriculares Nacionais. Temas Transversais: Meio Ambiente. Brasília: MEC/SEF, 1998.

Disponível

em: http://portal.mec.gov.br/seb/arquivos/pdf/ttransversais.pdf. Acesso em 07 de jan. 2012.

BRASIL. Parecer CNE/CP no 9 de 8 de maio de 2001. Diretrizes Curriculares Nacionais para a Formação de Professores da Educação Básica, em nível superior, curso de licenciatura, de graduação plena. Disponível em: http://portal.mec.gov.br/cne/arquivos/pdf/009.pdf. Acesso em 25 de mai. 2012. BRASIL. Resolução no 60 de 20 de novembro de 2009.

BRONOWSKI, J. Science and Human Values. Nova lorque: Julian Messner Inc., 1956.

BROWN, T. L.; LeMAY, H.; BURSTEN, B. E. Química: ciência central. São Paulo: Pearson Prentice Hall, 2005.

CHANG, Raymond. Química Geral - Conceitos essenciais. São Paulo: McGraw-Hill, 2007.

DIVISÃO DE BIBLIOTECA E DOCUMENTAÇÃO DO CONJUNTO DAS QUÍMICAS. Histórico. São Paulo, s.d. Disponível em: http://www.bcq.usp.br/biblioteca.php?id=1. Acesso em 19 de nov. 2015.

FERNANDES, Maria A. M.; PORTO, Paulo A. Investigando a presença da história da ciência em livros didáticos de Química Geral para o ensino superior. Química Nova, v. 35, p. 420-429, 2012.

GARRITZ, Andoni; CHAMIZO, José A. Química. Delaware: Addison-Wesley Iberoamericana, 1994. 
HOFFMANN, Roald. The same and not the same. Nova lorque: Columbia University Press, 1995.

HORVÁTH, István T. Green Chemistry. Accounts of Chemical Research, v. 35, n. 9, p. 685, 2002.

KNIGHT, David. Ideas in Chemistry - A history of the science. New Brunswick (EUA): Rutgers University Press, 1992.

KOTZ, J. C.; TREICHEL, P. Jr. Química e reações químicas. Rio de Janeiro: LTC, 2002.

KOVAC, Jeffrey. Scientific Ethics in Chemical Education. Journal of Chemical Education. v. 73, n. 10, p. 926-928, 1996.

KOVAC, Jeffrey. Professionalism and ethics in chemistry. Foundations of Chemistry. v. 2, p. 207-219, 2000.

KOVAC, Jeffrey. The Ethical Chemist. Upper Saddle River: Pearson Prentice Hall, 2004.

KRASILCHIK, Myriam. Ensino de ciências e a formação do cidadão. Em Aberto, Brasília, n. 40, p. 55-60, 1988.

LASZLO, Pierre. On the Self-Image of Chemists, 1950-2000. HYLE International Journal for Philosophy of Chemistry, v. 12, n.1, p. 99-130, 2006.

LOPES, Alice Casimiro. Currículo e epistemologia. In: ROSA, Maria Inês. Resenhas. Revista Brasileira de Educação. v. 12, n. 36, 2007.

MAUSKOPF, Seymour H. (ed.) Chemical Sciences in the Modern World. Filadélfia: University of Pennsylvania Press, 1993.

NASCIMENTO, Aparecida Maria do; MACEDO, Nael Ferreira do; OLIVEIRA, Maria José Houly Almeida de. Livro didático de química: uma análise da 
prática de contextualização e seu uso nas escolas públicas estaduais de Arapiraca. V Colóquio Internacional "Educação e Contemporaneidade", São Cristóvão, 2001.

NATIONAL ACADEMIES, The. On Being a Scientist. Washington: The National Academies Press, 2009.

NETO, Jorge Megid; FRACALANZA, Hilário. O livro didático de ciências: problemas e soluções. Ciência e Educação. v. 9, n. 2, p. 147-157, 2003.

NYE, Mary Jo. From chemical philosophy to teorethical chemistry Dynamics of matter and dynamics of disciplines, 1800-1995. Berkeley: University of California. 1993.

RIOS, Terezinha Azerêdo. Ética e competência. São Paulo: Cortez Editora, 1993.

RIOS, Terezinha Azerêdo. Ética na formação e no trabalho docente: para além de disciplinas e códigos. In: DALBEN, Ângela I. L. de F.; PEREIRA, Júlio E. D.; LEAL, Leiva, F. V.; SANTOS, Lucíola L. de C. P. (orgs.) Convergências e tensões no campo da formação e do trabalho docente. Belo Horizonte: Autêntica, 2010.

RUSSELL, Colin A. A química na sociedade. In: HALL, N. (ed.) Neoquímica. Porto Alegre: Bookman, 2004, pp. 365-379.

RUSSELL, Colin A., ROBERTS, Gerrelyn K. Chemical History: Reviews of the Recent Literature. Londres: RSC Publishing, 2006.

SCHUMMER, Joachim. Dealing with radical change and material complexity:an introduction to the philosophy of chemistry. In: Philosophy of the Special Sciences. Nova lorque: Suny Press, 2008. 
SCHUMMER, Joachim. Ethics of chemical synthesis. Hyle - International Journal for Philosophy of Chemistry. v. 7, p. 103-124, 2001.

SEVERINO, Antônio Joaquim. Formação e atuação dos professores: dos seus fundamentos éticos. In: DALBEN, Ângela I. L. de F.; PEREIRA, Júlio E. D.; LEAL, Leiva, F. V.; SANTOS, Lucíola L. de C. P. (orgs.) Convergências e tensões no campo da formação e do trabalho docente. Belo Horizonte: Autêntica, 2010.

SICCA, Natalina A. L., GONÇALVES, Pedro W. História da Química e da Geologia: Joseph Black e James Hutton como referências para educação em ciências. Química Nova, v. 25, n. 4, p. 689-695, 2002.

SJÖSTRÖM, Jesper. The discourse of chemistry (and beyond). Hyle International Journal for Philosophy of Chemistry. v. 13, n. 2, p. 83-97. 2007.

SOUZA, Karina. A. F. D.; MATE, C. H.; PORTO, P. A. História do uso do livro didático Universitário: o caso do Instituto de Química da USP. Ciência e Educação, v. 17, p. 679-694, 2011.

TORRESI, Susana I. Córdoba de; PARDINI, Vera L.; FERREIRA, Vitor F. Ética nas publicações científicas. Química Nova, v. 31, n. 2, p. 197, 2008.

VÁZQUEZ, Adolfo Sánchez. Ética. Rio de Janeiro: Civilização Brasileira, 1975.

VIANA, Hélio E. B. A construção da teoria atômica de Dalton como estudo de caso - e algumas reflexões para o ensino de química. 2007. Dissertação (Mestrado em Ensino de Ciências - Modalidade Química), Universidade de São Paulo, São Paulo, 2007.

ZIMAN, John. Conhecimento público. São Paulo: Itatiaia, 1979. 
ZOLLER, Uri. Chemistry and Environmental education. Chemistry education: research and practice. v.5, p. 95-97, 2004. 